This is a preprint of the article submitted to Basin Research. This article is underreview for publication and subsequent versions of this article may have different content. If accepted, the final version of this article will be available via the 'Peerreviewed Publication DOl' link on this webpage.

Please feel free to contact the authors directly. Feedback is welcome. 


\title{
Influence of minibasin obstruction on canopy dynamics in the northern Gulf of Mexico
}

\author{
Naiara Fernandez*, Oliver B. Duffy, Frank Peel, Michael R. Hudec \\ Bureau of Economic Geology, Jackson School of Geosciences, The University of Texas \\ at Austin, University Station, Box X, Austin, Texas, 78713-8924, USA \\ *Corresponding author: naiara.fernandez@beg.utexas.edu
}

Abstract
In salt-detached gravity-gliding/spreading systems the detachment geometry is a key control on the downslope mobility of the supra-salt sequence. Here we used regional $3 D$ seismic data to examine a salt-stock canopy in the northern Gulf of Mexico slope, in an area where supra-canopy minibasins subsided vertically and translated downslope above a complex base-of-salt. If thick enough, minibasins can interact with, and weld to, the base-of-salt and be obstructed from translating downslope. Based on the regional maps of the base of allochthonous salt and the base of the supra-canopy sequence, the key controls on minibasin obstruction, we distinguished two structural domains in the study area: a highly obstructed domain and a highly mobile domain. Large-scale translation of the supra-canopy sequence is recorded in the mobile domain by a fartravelled minibasin and a ramp syncline basin. These two structures suggest downslope translation on the order of $40 \mathrm{~km}$ from Plio-Pleistocene to Present. In contrast, translation was impeded in the obstructed domain due to supra-canopy bucket minibasins subsiding into feeders during the Pleistocene. As a result, we infer that differential translation occurred between the two domains and argue that a deformation area between two differentially translating supra-canopy minibasin domains is difficult to recognize. However, characterizing domains according to base-of-salt geometry and supra-canopy minibasin configuration can be helpful in identifying domains that may share similar subsidence and downslope translation histories. 


\section{Introduction}

In passive-margin salt basins, a regional slope facilitates the formation of saltdetached gravity-gliding/spreading systems (Cobbold and Szatmari, 1991; Jackson et al.,

33 1994; Schultz-Ela, 2001; Hudec and Jackson, 2004; Brun and Fort, 2004, 2011; Peel,

34 2014). If a homogeneous sedimentary cover detaches over a smooth base-of-salt, 35 kinematically linked domains of upslope extension and downslope shortening develop 36 (e.g. Cobbold and Szatmari, 1991; Brun and Fort 2004, 2011; Hudec and Jackson, 2004;

37 Rowan et al., 2004). However, in areas where the translation occurs above a high-relief 38 base-of-salt, strain patterns are more complex (e.g. Gaullier et al., 1993; Loncke et al., 2006; Dooley et al., 2017a, b; 2018; Pichel et al., 2019a,b).

Kinematically linked systems also occur above allochthonous salt canopies. However, strain patterns above salt canopies can be complicated largely due to interactions between the supra-canopy minibasins and the extreme relief on the base-of-salt (e.g. Krueger, 2010; Duffy et al. 2019). Duffy et al. (2019) present an example from the mid-to-lower slope of the northern Gulf of Mexico, a setting characterized by a high-relief base-of-salt overlain by a heterogeneous system of supra-canopy minibasins. The authors propose that as minibasins subsided into the canopy, they also translated downslope. Thus, when minibasins are thick enough, they can weld against the high-relief base-of-salt and become obstructed from freely translating downslope. Importantly, minibasins can be obstructed to different degrees depending on the weld geometry. For example, severelyobstructed minibasins (e.g. minibasins welded laterally against vertical feeder walls, also known as bucket minibasins) may cease translating completely, whereas mildlyobstructed minibasins may simply slow down (Duffy et al., 2019). As the downslope flow of salt and the supra-canopy sequence continues around obstructed minibasins the local strain field is modified, with zones of shortening typically developing immediately upslope of the obstructed minibasins, and extensional breakaways immediately downslope 56 (Krueger, 2010; Duffy et al., 2019).

An implication of the minibasin obstruction model is that adjacent minibasins on the slope can be obstructed to different degrees, and thus differential degrees of

59 downslope translation can occur. The differential translation of variably obstructed 
60 minibasins should be accommodated by 3D strains and strike-slip deformation (Rowan 61 et al., 1999; Krueger, 2010; Duffy et al., 2019), however, such deformation can be difficult

62 to recognize in salt-detached systems. Critically, it is unknown how important the 63 principles of minibasin obstruction are at larger scales. For example, can entire portions 64 or domains of supra-canopy sequence be variably obstructed and influence the dynamics 65 of salt-canopy advance? Furthermore, if differential translation occurs between minibasin 66 domains, can we identify the structures that accommodate that deformation? 67 Characterizing domains according to the structural configuration of minibasin obstructing elements can be helpful in identifying areas where minibasins may share similar subsidence and downslope translation stories, which is ultimately useful for basin structural and depositional reconstructions through time and for regional strain analyses.

Here, we apply the minibasin obstruction model to an area containing numerous minibasins that are subsiding into a salt canopy and that are translating downslope above a high-relief base-of-salt. First, we examine the morphology of the base-of salt and the configuration of overlying supra-canopy minibasins. We couple this with observations of the structural styles observed in downslope oriented seismic cross-sections to constrain the style and degree of minibasin obstruction across the study area. Based on the spatial distribution of minibasin obstruction, we then define two broad domains with different potential for downslope translation and mobility: 1) a highly-mobile unobstructed domain and 2) a highly-obstructed domain. Second, we document and describe striking evidence

80 for large-magnitude downslope translation in the highly-mobile domain (a ramp syncline 81 basin and a far-travelled minibasin) that have not been recognized in the obstructed 82 domain. Third, we describe the area that accommodates the differential translation 83 between the two domains, and discuss the implications of the timing of differential 84 translation on the mappability of such an area.

\section{Data and Methods}

The study area is located in the northern Gulf of Mexico in the mid-to-lower slope

(Fig. 1). We focus on an area of $13,100 \mathrm{~km} 2$ covered by two 3D pre-stack, depth-migrated, seismic reflection surveys that image to $18 \mathrm{~km}$ depth. The seismic data are presented 
such that a downward increase in acoustic impedance is marked by a peak (black on seismic sections).

The seismic data was provided by WesternGeco Multiclient and CGG and are

92 commercially sensitive, so the precise geographic location cannot be released. All maps

93 are rotated, and for the ease of description, any geographical cardinal references within

94 this work are given in the framework of an arbitrarily defined "North". Location of seismic

95 sections cannot be released, neither the absolute depth of sections. However, the 96 basinward direction is indicated in the sections, all of which have a coarsely "NW"-"SE" 97 orientation (with respect to the arbitrary "North").

98 Three surfaces have been mapped in the study area: the base Sigsbee canopy, 99 the top Sigsbee canopy, and the seabed (Fig. 2). Of these surfaces, the deepest is the 100 base Sigsbee canopy (sometimes referred to as base-of-salt in the text), a composite 101 surface that for the most part corresponds to the top of the primary sedimentary sequence 102 or top primary minibasin (sensu Pilcher et al., 2011). Although the overall seismic quality 103 is good, the data contains some shadow areas and data-wipeout zones at depth that 104 require a careful interpretation of the base Sigsbee canopy. We have followed the 105 guidelines provided by Jackson and Hudec (2017) in order to avoid common pitfalls of 106 base-of-salt interpretation. This is especially important when interpreting feeders in the 107 study area. Where feeders are present, the base Sigsbee canopy surface extends down 108 the feeders and includes their flanks as well as their base, that corresponds to the deep 109 salt level (autochthonous or parautochthonous salt) (Fig. 2). The top Sigsbee canopy 110 surface (sometimes referred to as top-of-salt in the text), corresponds to the base of the 111 supra-canopy sedimentary sequence and thus, highlights the geometry of the supra112 canopy minibasins (Fig. 2). We used the base-of-salt and top-of-salt horizons to calculate 113 the thickness of the supra-canopy sedimentary sequence. Due to the relatively low 114 amplitude relief of the seafloor compared to the top Sigsbee canopy, the supra-canopy 115 thickness map reproduces the geometric configuration of the top Sigsbee canopy (top-of116 salt) horizon. For consistency, we refer to the top Sigsbee canopy horizon, instead of the 117 thickness map, to describe and discuss the supra-canopy minibasin configuration (Fig. 118 2). Where available, surface picks based on biostratigraphic markers from BOEM well119 data were used to assign an age to the interpreted horizons. 
The Gulf of Mexico started opening when South America moved away from North

122 America, during the breakup of Pangea in the Late Triassic (e.g. Pindell and Dewey, 1982;

123 Salvador, 1991). The basin continued growing during a second phase of rifting, when the

124 Yucatan block moved away from North America during Late Jurassic (e.g. Pindell and

125 Dewey, 1982; Salvador, 1991). Deposition of Jurassic Louann salt occurred when the

126 Gulf of Mexico basin was isolated from greater ocean circulation during rifting (e.g.

127 Salvador, 1987). The Louann salt is variable in thickness, reflecting the rift-related

128 topography, and is absent over most of the oceanic crust in the central parts of the Gulf

129 of Mexico (e.g. Worral and Snelson, 1989; Sawyer et al., 1991; Peel et al., 1995; Hudec

130 et al., 2013; Pindell et al., 2014, 2018; Curry et al., 2018; Rowan, 2014, 2018). In the

131 northern Gulf of Mexico, salt was loaded by sediments and probably mobilized since Late

132 Jurassic (e.g. Nettleton, 1955; Peel et al., 1995; Rowan et al., 1995), when deposition

133 was dominated by marine carbonates, with localized clastic inputs (e.g. Salvador, 1987,

134 1991; Galloway et al., 1991; Galloway, 2008). During the Cenozoic, large volumes of 135 clastic sediments were deposited in the Northern Gulf of Mexico, which forced the shelf 136 margin to prograde hundreds of kilometers (e.g. Galloway et al., 1991; Galloway, 2008).

137 The loaded autochthonous salt was able to flow into diapirs that rose thorough the primary

138 stratigraphic sequence so that salt was emplaced onto higher stratigraphic levels forming 139 allochthonous salt sheets. The Sigsbee Salt Canopy was formed through coalescence of 140 many of these salt sheets (e.g. Wu et al., 1990b; Peel et al., 1995; Diegel et al., 1995; 141 Rowan et al., 1995). Neogene to Recent sediments have been deposited on top of the 142 Sigsbee canopy, forming secondary or supra-canopy minibasins (e.g. Worral and 143 Snelson, 1989; Wu et al., 1990a, b; Diegel et al., 1995; Peel et al., 1995, Pilcher et al., 144 2011). As the canopy salt flowed downslope assisted by gravity, so did the supra-canopy 145 minibasins. Minibasins were thus translating downslope at the same time as they were 146 subsiding into the salt.

147 The bathymetry map of the northern Gulf of Mexico (Fig. 1) illustrates the location 148 and extent of the Sigsbee Canopy. The Sigsbee canopy is located basinwards of the shelf 149 edge (Fig. 1). Here, the nature of the seafloor is rugose with numerous topographic lows, 
each of which corresponds to a supra-canopy minibasin. The Sigsbee Escarpment is the prominent topographic feature that marks the basinward limit of the salt canopy (Fig. 1).

In the study area, the two levels of salt can be observed in a seismic section oriented along strike of the slope (Fig. 2). The deepest level of salt corresponds to the autochthonous Louann salt (the stratigraphic level) but can, in places, also correspond to parautochthonous salt extruded on top of crust being created or exhumed during the opening of the Gulf of Mexico (e.g. Sawyer et al., 1991; Peel et al., 1995; Hudec et al., 2013; Norton et al., 2016). In most cases, the Louann salt has been completely evacuated from this deep level and only welds remain. The shallow level of salt corresponds to the Sigsbee salt canopy. Salt feeders are the diapirs through which salt moved from its source layer to "feed" the allochthonous salt sheets. Due to shortening, feeders may be closed, with the walls of the feeders welded against each other. Where the feeders remain open, they may be filled with supra-canopy minibasins.

\section{Morphology of Base Sigsbee Canopy and Supra-Canopy Minibasins}

Two key elements must be considered for assessing the potential for minibasin obstruction to occur: 1) the relief of the base Sigsbee Canopy (base-of-salt); and 2) the thickness of supra-canopy minibasins (configuration of the top Sigsbee Canopy or top-ofsalt horizon). When the configuration of these two elements allows for welding of a minibasin, minibasin obstruction can occur. We will describe these two key elements in the study area.

\section{Base Sigsbee Canopy Relief}

The base Sigsbee Canopy surface is highly rugose with relief exceeding $15 \mathrm{~km}$ in 172 some areas (Fig. 3a). Feeders connecting the deep salt level or equivalent weld with the 173 shallow salt are clearly visible on the mapped surface as sub-circular to elliptical low areas 174 bounded by vertical to sub-vertical walls that are 7-8 km tall (Fig. 3a). Feeder diameters 175 are in the range of 10 to $15 \mathrm{~km}$ but there are few instances of elongated feeders that are $17630 \mathrm{~km}$ long. Although the negative relief represented by feeders is remarkable, feeders 177 are not the only elements that influence the topography of the surface. The morphology 178 of the top primary basins also influences the overall relief of the base Sigsbee canopy.

179 The top of the sub-canopy basins varies from being smooth and almost flat in some areas, 
180 to being highly rugose in areas, with localized positive relief in the form of protrusions and 181 narrow ridges (Fig. 3a).

The structure map of the top Sigsbee canopy (top-of-salt) corresponds to the base

184 of the supra-canopy minibasins (Fig. 3b). As such, the surface illustrates the geometry 185 and configuration of the supra-canopy minibasins. Minibasins are expressed as 186 topographic lows that are sub-circular, elliptical or highly irregular in shape. Over 50 187 minibasins are present in the study area, with thicknesses ranging between $2 \mathrm{~km}$ to 13 $188 \mathrm{~km}$. Minibasins are bounded by an irregular network of salt massifs and walls (topographic 189 highs in the structure map) (Fig. 3b). Typically, supra-canopy minibasins are surrounded 190 by salt at deep levels, whereas at shallower levels, they are yoked together by sediment 191 beams (Fig. 2).

\section{Spatial Variations in Minibasin Obstruction Styles}

193 Having established that minibasin obstruction is primarily controlled by the 194 relationship between the base-of-salt surface and the configuration of the overlying supra195 canopy minibasins, and having described these two elements in our study area, we now 196 examine the spatial distribution of obstructed minibasins. Both the base-of-salt relief and 197 the minibasin configuration are variable across the study area and we use these 198 variations to classify two domains: the "Northeast" and "Southwest" domains. Seismic 199 sections oriented roughly parallel to the downslope translation direction (Fig. 4 and 5) 200 highlight key differences between these two domains (exact line locations are withheld 201 for data confidentiality reasons).

\section{Structural Style of the "Southwest" Domain}

204 "Southwest" compared to the "Northeast" (Fig. 3a). Also, in the "Southwest", areas 205 between feeders exhibit higher topographic relief, with more positive relief features such 206 as ridges, resulting in a highly rugose form (Fig. 3a). In general, the domain shows a high207 relief base-of-salt with a well-developed egg-crate-like morphology that is not present in 
208 the "Northeast". In addition, thicker minibasins are more common in the "Southwest" than 209 in the "Northeast" (Fig. 3b).

210 Two seismic cross sections from the "Southwest" highlight the interaction between 211 the high relief base-of-salt and the thicker minibasins (Fig. 4). One of the seismic sections 212 represents an area with abundant feeders (Fig. 4a), whereas the other shows only two 213 feeders, one of which is welded shut (Fig.4b). The base Sigsbee Canopy is not flat, with 214 many local highs and steep zones (Fig. 4b). In both seismic sections, supra-canopy 215 minibasins are welded at their base or at the flanks on top of primary basins or in contact 216 with feeder flanks. In fact, all feeders in the seismic section contain minibasins that have

217 sunk into the feeders to varying degrees (bucket minibasins). A minibasin may sink all the 218 way down into the feeder and weld at their base at the deep salt level (see example in 219 Figs. 4a and b). Alternatively, minibasins may sink only partway into the feeder. Several 220 examples of minibasins partially sunk into the feeder are present in the seismic section 221 (minibasins denoted "a", "b" and "c"; Fig. 4a). Thus, the "Southwest" domain is not only 222 characterized by the presence of abundant wide feeders, but also by the fact that in most 223 cases these feeders are filled with bucket minibasins (Fig. 4a and 6a).

\section{Structural Style of the "Northeast" Domain}

Overall, there are fewer identified feeders in the "Northeast" domain, and they are smaller and narrower than the ones in the "Southwest" (Fig. 3a). Areas surrounding the feeders in the "Northeast" exhibit a relatively smooth and flat topography with limited relief on base Sigsbee Canopy surface (Fig. 3a). Furthermore, minibasins in the "Northeast" domain are generally thinner and shallower, and more frequently closely clustered or connected through sediment beams than in the "Southwest" (Fig. 3b).

Two seismic sections from the "Northeast" illustrate the relationships between the supra-canopy minibasins and the base-of-salt (Figs $5 a$ and b). In some areas, the base 234 Sigsbee Canopy surface is very continuous and not disrupted by any feeders (Fig. 5a), 235 whereas in other areas feeders are present, but they are surrounded by a relatively 236 smooth base-of-salt (Fig. 5b). The overlying minibasins are welded against a smooth or 237 gently dipping base-of-salt (Fig. 5a), or alternatively, the minibasins are not thick enough 238 to be welded to the base-of-salt (Fig. 5 b). In any case, the supra-canopy minibasins in 
239 the "Northeast" domain are not thick enough to have completely sank into the feeders 240 (Fig. 5b). In summary, the "Northeast" domain shows fewer and smaller feeders than the 241 "Southwest", with no bucket minibasins developed (Fig. 5 and 6a).

\section{Differential Potential Mobility of the "Southwest" and "Northeast" Domains}

Given that the "Northeast" domain contains fewer highly-to-severely obstructed minibasins than the "Southwest" domain (Fig. 6b), it is likely to have higher degree of mobility, compared to the severely-obstructed supra-canopy sequence in the "Southwest" domain (Fig. 7a). Structural styles and potential mobility of the two domains are represented by the synoptic sections presented in Figs. $7 \mathrm{~b}, \mathrm{c}$ and $\mathrm{d}$.

\section{Evidence for large-magnitude downslope translation in the}

\section{'Northeast' Domain}

The mid-to-lower slope of the northern Gulf of Mexico is a translational domain of 252 a salt-detached gravity-gliding system. Estimating the magnitude of translation in the 253 translational domain is difficult for two reasons. First, due to the heterogeneously thick 254 cover sequence where minibasins are abundant, clear structural indicators of movement 255 such as fault cutoffs are not common (Jackson and Hudec, 2005). Second, as described 256 in Duffy et al., 2019, strain patterns in the translational domain can be extremely complex, 257 with localized areas of shortening and extension surrounding obstructed minibasins. Two 258 lines of evidence can be used to constrain the amount of translation of the supra-canopy 259 sequences within the translational domain: 1) rafted blocks or far-travelled minibasins 260 (e.g. Jackson et al., 2010, Fiduk et al., 2014) and 2) salt-detached ramp synclines (herein 261 termed RSBs, Pichel et al., 2018) (e.g. Jackson and Hudec, 2005) (Fig. 8). Here we 262 provide examples of each of these structures to constrain the amount of down-slope 263 translation of the supra-canopy sequence in the study area.

Far-travelled minibasins

Transported or rafted sediment packages, including entire minibasins and 267 carapace blocks, can provide estimates of translation magnitude if the upslope location 
268 where the package originated can be identified (e.g. Jackson et al., 2010) (Fig. 8a). As it 269 moves downslope, extruded salt can transport supra-salt stratal packages (e.g. carapace 270 sections of up to $25 \mathrm{~km}$-wide and up to few kilometers in thickness; Hart et al. 2004). 271 Rafted blocks have been documented across the northern Gulf of Mexico (e.g. Jackson 272 et al., 2010; Pilcher et al., 2014, Fiduk et al., 2014). Rafted carapace blocks containing 273 Mesozoic-age carbonates could have travelled tens of kilometers (>100 km) away from 274 the salt structure on which they were originally deposited as roof material (Fiduk et al., 275 2014).

In some instances, transported supra-salt stratal packages are entire minibasins 277 that contain stratigraphic duplicates of the subsalt sedimentary sections that lie below 278 them (e.g. Mount et al., 2006; Jackson et al., 2010) (Fig. 8b). If an entire minibasin was 279 transported by salt, it must have left a "gap" or "hole" in the subsalt stratigraphic sequence 280 big enough to fit the entire transported stratigraphic package. Identifying the source area 281 of a specific transported stratal package can provide insights into lateral transport 282 magnitudes as well as minimum required salt thickness (Jackson et al., 2010).

In the "Northeast" domain, we have identified three minibasins that contain a 285 sub-canopy primary sequence of Mesozoic to Miocene age. The duplication of Mesozoic 286 to Miocene section in a supra-canopy minibasin implies that the minibasin must have 287 originated somewhere upslope of its current position. The biggest of these three 288 minibasins contains over 3500 meters of duplicated stratigraphic sequence with an area 289 of $12 \times 13$ kilometers (Fig. 9). The other two minibasins contain around 2000 meters of 290 duplicated sequence and they are smaller in extent. Upslope of these three minibasins 291 there are few areas from where the sub-canopy Mesozoic to Miocene stratigraphic 292 sequence is missing (feeders) that are big enough to fit these minibasins. The nearest 293 potential source area from where the minibasin with the thickest duplicated stratigraphic 294 section could have originated corresponds to a large feeder located up-slope (Fig. 9). The 295 distance from the minibasin to this potential source area is around $40 \mathrm{~km}$. This implies 296 that the minibasin was rafted at least $40 \mathrm{~km}$ downslope from its source area. Presumably, 297 the minibasin was thinner when it was uplifted from its source area and it became thicker 298 as it translated downslope. 
300 Salt-detached RSB's are growth synclines that form by translation of the 301 sedimentary cover above a stepped salt detachment (e.g. Jackson and Hudec, 2005) 302 (Fig. 8c). Salt-detached ramp syncline basins were first recognized as indicators of the 303 translation of the sedimentary cover in the Kwanza Basin, Angola (Marton et al., 1998; 304 Peel et al., 1998 and Spencer et al., 1998). Identification and description of RSBs in other 305 places have provided insights into the evolution of salt-bearing basins such as the Santos 306 and Campos Basins in Brazil (e.g. Dooley et al. 2016; Pichel et al., 2018) and the Red 307 Sea (e.g. Rowan, 2014) for example. Assuming the underlying ramp was fixed, the 308 distance between the top of the ramp and a given onlap point records the translation 309 distance since the deposition time of the horizon forming the onlap (Jackson \& Hudec, 310 2005) (Fig. 8c).

311 In the "Northeast" domain, in an area of relatively low topographic relief of the sub312 canopy section, we have identified a structure that we interpret as an RSB (Fig. 10). The 313 base Sigsbee Canopy has a gentle landward slope for several tens of kilometers, with 314 steeper seaward-dipping slope landward (the ramp). The supra-canopy section above the 315 ramp-to-flat transition has a basal and, for most of the part, constant-thickness sequence, 316 that we interpret as a prekinematic preramp wedge (Fig. 10). The overlying sedimentary 317 sequence (Fig. 10), has a basal isopach thick on top of the basinward edge of the pre318 ramp sequence. The overlying isopach thicks have their depocenters successively shifted 319 landward with respect to the underlying one forming a characteristic RSB geometry. An 320 onlap surface separates the RSB and underlying pre-wedge sequence. The horizontal 321 distance between the edge of the ramp and the onlap point of the oldest isopach thick on 322 top of the pre-ramp wedge is $\sim 40 \mathrm{~km}$. The sub-canopy ramp is not completely imaged 323 within the seismic data and therefore the position of the transition from the ramp to the 324 landward flat is not exactly known. Thus, $\sim 40 \mathrm{~km}$ is the minimum downslope translation 325 that occurred from the time the lowermost isopach thick was deposited. This magnitude 326 is similar to the translation estimated for the far-travelled minibasin. 
Synoptic cross sections help illustrate the evolution of the two domains (Fig. 11).

330 In an early stage, because the supra-canopy minibasins are thin, they freely move 331 downslope, regardless of the underlying geometry of the base-of-salt relief (Fig. 11a).

332 However, as the minibasins translate downslope they become thicker. In the "Southwest"

333 Domain, where the bigger feeders are present, supra-canopy minibasins can experience

334 an increased subsidence as they pass over feeders containing thick salt where salt 335 evacuation is easier. Subsequently, minibasin subsidence is fixed in place over the feeder 336 and forms a bucket minibasin (Fig.11b). Bucket minibasins are welded to the feeder walls 337 and thus are severely obstructed (Fig.11b). The severe obstruction impedes further 338 minibasin translation and creates the characteristic upslope shortening and downslope 339 extension strain pattern described by Duffy et al. (2019) (represented in Fig. 11b and c). 340 In the "Northeast" Domain instead, the smoother base of salt relieve does not enable the 341 formation of bucket minibasins and thus, the supra-canopy minibasins can continue their 342 downslope translation (Fig.11b). The different degree of obstruction results in differential 343 advance of the supra-canopy cover that is accommodated in between the two domains 344 (Fig. 11c). But when was the "Southwest" Domain obstructed, and the differential 345 translation accommodated?

346 According to our interpretation of the seismic and available age constraints from 347 well data, sometime during the Upper Miocene to Pliocene, the far-travelled minibasin 348 (Fig. 9), was lifted from its source diapir because salt in the diapir was actively rising. At 349 that time, the minibasin was probably thinner than at present day, thus it was easier to lift 350 it out of the diapir. After being lifted, the minibasin started its downslope translation leaving 351 behind an unroofed diapir and becoming thicker during its downslope translation as new 352 sediments were accumulated on top. At present, this source-diapir contains a bucket 353 minibasin (Fig. 9). It is not possible to know exactly how far upslope from the feeder the 354 bucket minibasin formed or nucleated. Considering our own translation estimates for the 355 "Northeast" domain as well as existing estimates in other areas of the northern Gulf of 356 Mexico (e.g. Fiduk et al., 2014), the translation of these minibasins could have been in 357 the order of few-tens of kilometers. However, interpreted stratal geometries and available 358 age constraints indicate a transition to a wedge-shaped stratigraphic package (increased 
asymmetric subsidence) of the bucket minibasin at around the Plio-Pleistocene marker

360 (Fig. 9). Based on this interpretation, we suggest that the minibasin was translated over 361 and subsided into the feeder during the Plio-Pleistocene to Early Pleistocene (ca. 2.30$3621.39 \mathrm{Ma}$ ) (Fig. 9). The down-dip time-equivalent of the wedge-shaped sequence in the 363 bucket-minibasin corresponds to a constant-thickness sequence in several other 364 minibasins (including the far-travelled minibasin). Due to the increased subsidence, the 365 minibasin became "trapped" into the feeder and was therefore severely-obstructed from 366 translating downslope. Subsequent subsidence (Pleistocene, after 1.39 Ma) occurred as 367 it sank further into the feeder. Directly down-dip of the bucket minibasin, an area of 368 extension accommodated the differential translation between the obstructed bucket 369 minibasin (effectively locked) and the down-dip minibasins (e.g. Duffy et al., 2019) (Fig. 370 9) within the mobile domain. In the "Southwest" domain, there are other instances of 371 bucket-minibasins completely filling the feeders (Fig. 6a). Limited available age data 372 suggests that at least one other bucket minibasin was probably in its present position, 373 above the feeder, by mid-Pleistocene (before $1.39 \mathrm{Ma}$ ). Thus, we suggest that the cover 374 sequence in the "Southwest" domain was probably severely-obstructed by mid375 Pleistocene.

In contrast, based on the interpretation of the stratal geometries and available age constraints, the RSB recorded continuous translation from Pliocene or earlier to Present378 Day in the "Northeast" domain (Fig. 10). Based on the onlap position of the Plio379 Pleistocene $(2.30 \mathrm{Ma})$ marker, the RSB translated at least $5 \mathrm{~km}$ farther during that time 380 interval (Fig. 10). Thus, the severe obstruction of the "Southwest" domain and coeval 381 translation of the "Northeast" domain must have resulted in differential translation 382 between the two domains from Pleistocene to Present.

383 We have mapped the Sigsbee canopy front advance based on the interpretation 384 and mapping of stratigraphic salt-cutoffs in the study area (Fig. 12b). There was 385 differential salt advance of the Sigsbee canopy front during the same time interval when 386 we propose the differential translation between the two domains occurred (Fig. 11c and 387 12b). As stated by the obstruction model, salt can flow around obstructed minibasins, 388 which is ultimately the reason for the complex strain patterns around minibasins (Krueger, 389 2010; Duffy et al., 2019). However, assuming that at geological time scales salt behaves 
as a fluid of very high viscosity, its resistance to flow around the obstructed (immobile) 391 minibasins is high. Thus, it is harder for salt to flow downslope in the "Southwest" domain 392 were many obstructed/bucket minibasins are present. In contrast, in the "Northeast" 393 domain, salt has less obstacles to flow around. The differential salt advance can be 394 observed in the mapped front of the Sigsbee canopy (Fig. 12b). The amount of differential 395 salt advance is in the order of few kilometers in our study area, similar to the estimated 396 translation of the RSB at the same time interval.

How is Differential Translation between Minibasin Domains

Given the present-day configuration of the two domains in our study area, we have established that they have different potential mobility. We have also suggested, that the "Southwest" domain was obstructed earlier and there has been differential translation between the two domains from Pleistocene to Present. The questions that follow are: is the differential translation reflected in the supra-canopy sequence? Is this differential deformation still active?

Differential translation of supra-canopy sequence should be accommodated by 3D strains and deformation (e.g. Rowan et al., 1999; Krueger, 2010; Pichel et al., 2019a). Differential translation between portions of the supra-canopy sequence have been identified in some areas in the northern Gulf of Mexico, where well-defined strike-slip tear faults accommodate this movement. For example, the submarine Keathley Canyon is located where the Sigsbee Escarpment changes its orientation from a W-E trend to a NWSE trend (Fig. 1 and 12a). There, a pull-apart basin and associated releasing bends indicate the existence of a long and straight left-lateral strike slip zone following the overall trend of the Keathley Canyon (Fig. 12a) (e.g. Dooley and Schreurs, 2012). This structure has been interpreted as a NW-striking strike-slip zone that separates two structural provinces of the northern Gulf of Mexico with different amounts of translation of the supracanopy cover. In areas where the base-of-salt is smooth and planar, differential deformation is accommodated by long and linear tear faults (e.g. in areas of the eastern and northern Gulf of Mexico; e.g. Rowan et al., 1999; Krueger, 2010). However, in areas where the supra-canopy minibasins interact with a very irregular base-of-salt canopy and 
420 downslope translating minibasins are obstructed, more complex strain patterns arise 421 (Rowan et al., 1999; Krueger, 2010; Duffy et al., 2019). Differential deformation can be 422 expected to be accommodated in short fault segments bounding minibasins, instead of in 423 long and linear strike-slip faults.

$424 \quad$ Using seismic data and seafloor bathymetry, we have mapped several seafloor 425 structures in our study area. No long straight right-lateral strike-slip fault spanning across 426 the boundary between the two domains has been identified in the seafloor. Instead, 427 mapped structures correspond to extensional faults with a mainly dip-slip component that 428 bound supra-canopy minibasins that may form conjugate sets with opposite dipping 429 directions defining graben structures (Fig. 12b). In some instances such normal faults are 430 grouped into sets, roughly parallel to the downslope transport direction (Fig. 11b). In many 431 other cases, the groups of normal faults strike perpendicular to the transport direction 432 (Fig. 12b). The latter correspond to extensional breakaways formed immediately 433 downslope of obstructed minibasins (e.g., Duffy et al., 2019). Contractional structures 434 (mainly folds) have been mapped immediately up-dip of one of the severely-obstructed 435 minibasins that lies within a feeder (Duffy et al., 2019). To some degree, the overall 436 distribution of strain on the seafloor across the study area reflects the different structural 437 styles of the two described domains (obstructed vs. non-obstructed). While areas of 438 stretching are widespread across the study area, the identified shortening structures are 439 located in the "Southwest" domain (non-mobile) exclusively (Fig. 12b). In most cases, 440 these areas of shortening correspond to the up-dip shortening associated with obstructed 441 bucket minibasins (Fig. 6 and 12b).

442 In summary, instead of an easily identifiable zone of localized strike-slip 443 deformation between the two domains of our study area, a complex and diffuse strain 444 pattern with discrete structures distributed along minibasin boundaries is observed in the 445 seafloor. The absence of an area of localized strike slip deformation in the seafloor of the 446 study area can have two interpretations: 1) there is no ongoing differential translation or 447 deformation, or if there is, such deformation is not large enough to create a localized 448 linear strike-slip structure in the seafloor, or 2) differential translation is occurring, but 449 deformation between the two domains is being accommodated in a diffuse way, along 450 minibasin boundaries. 
Evidence for earlier stages of differential translation might be even more difficult to 452 identify than in the present-day for three reasons. First, as discussed for the present-day 453 case, earlier differential translation might have been accommodated by a diffuse zone 454 and distributed along minibasin boundaries in several shorter segments. Second, there 455 might have been no supra-canopy sequence deposited in between the minibasins that 456 would have recorded the differential translation, so that deformation would have been 457 accommodated by salt in a cryptic manner. Third, there may have been a supra-canopy 458 sequence that recorded the differential translation, but it was later eroded.

459 Observations from present-day structures in the seafloor do not show evidence for 460 a localized deformation area between the two described domains. However, the different 461 structural styles of the two domains (obstructed vs. non-obstructed, Fig. 7) are recorded 462 by a characteristic strain pattern distribution in the seafloor (Fig. 12b). While the 463 "Southwest" domain displays complex strain patterns with areas of both shortening and 464 extension related to severely obstructed minibasins, the "Northeast" domain displays 465 dominantly extensional deformation as the supra-canopy sequence translates downslope 466 without severe obstructed processes occurring at present. We argue that the 467 characteristic strain pattern distribution in the seafloor, indicates that the interpreted 468 structural styles (obstructed vs. non-obstructed) are exerting an influence in the presentday deformation of seafloor.

\section{Conclusions}

The aim of this study was to investigate if the concept of minibasin obstruction was

472 applicable beyond the scale of individual minibasins. In the study area we distinguished 473 two regional domains based on differences in the base Sigsbee Canopy surface geometry 474 and supra-canopy minibasin thickness, the two key elements in the obstruction process. 475 In the "Southwest" domain, the base-of-salt has high relief with abundant large feeders, 476 filled with thick bucket minibasins that are severely-obstructed from translating 477 downslope. In contrast, the "Northeast" domain is characterized by a base-of-salt that has 478 less relief, sparse and narrow feeders, and few bucket minibasins. We proposed that 479 when large portions of supra-canopy sequence contain multiple severely-obstructed 480 minibasins, each one behaves as a "pin" that "locks" the supra-canopy and sub-canopy 
481 sequences together, and the domain as a whole is severely-obstructed (i.e. the 482 Southwest' domain). In contrast, entire portions of the supra-canopy sequence containing 483 multiple minibasins that are unobstructed or mildly-obstructed are free to translate 484 downslope if the minibasins are too thin or shallow to interact with the base of salt or if 485 the base of salt is relative smooth (i.e. the 'Northeast' domain).

486 Large-magnitude downslope translation of several tens of kilometers is indicated 487 by two independent structures in the "Northeast" domain, a ramp-syncline and a far488 travelled minibasin. Translation of the supra-canopy sequence in the "Northeast" domain 489 seems to have been continuous from at least the early Pleistocene (and probably before) 490 through to the present-day, as recorded by a ramp syncline. In contrast, translation of the 491 supra-canopy sequence in the "Southwest" stopped during the Pleistocene, when several 492 bucket minibasins sank into feeders becoming severely-obstructed. The obstruction of 493 the "Southwest" domain would have resulted in differential translation, with the 494 "Northeast" domain able to translate further.

495 The deformation zone between differentially translating domains can be difficult to 496 recognize, depending on how such deformation is accommodated. In our study area, 497 seafloor structures suggest complex spatial patterns of local strain segments (extensional 498 breakaways, grabens, thrusts, folds) around minibasins. However, while stretching is the 499 dominant form of deformation across the study area, shortening structures (largely500 located immediately updip of severely-obstructed minibasins) are only found within the 501 less-mobile obstructed domain. This observation is in accordance with what the minibasin 502 obstruction model would predict around individual minibasins.

503 Predictions from the minibasin obstruction model are helpful in making sense of 504 complex strain patterns identified in the seafloor around individual minibasins. 505 Characterizing domains according to base-salt relief, supra-canopy minibasin 506 configuration and mobility potential within a slope setting can be helpful in identifying 507 areas that may share similar subsidence and downslope translation histories. Extending 508 the concepts of obstruction and differential mobility beyond the framework of individual 509 minibasins is thus key in understanding regional dynamics of supra-canopy deformation. 
We would like to thank Gillian Apps, Chris Jackson and Tim Dooley for scientific discussions and Nancy Cottington for her help with figure drafting. We thank reviewers

513 Scot Krueger, Leonardo Pichel and Sian Evans for their comments which helped improve

514 this work. Thanks to CGG and WesternGeco Multiclient for providing the 3D seismic data 515 and to the Bureau of Ocean Energy Management for seafloor imagery. We also thank the 516 Gulf of Mexico Basin Depositional Synthesis Project (GBDS) at The University of Texas 517 at Austin, specially Craig Fulthorpe, John Virdell and John W. Snedden, for providing the 518 well-data that was used to assign ages to the seismic horizons. The project was funded 519 by the Applied Geodynamics Laboratory (AGL) Industrial Associates program, comprising 520 the following companies: Anadarko, Aramco Services, BHP Billiton, BP, CGG, Chevron, 521 Condor, EcoPetrol, EMGS, ENI, ExxonMobil, Fieldwood, Hess, Ion-GXT, Midland Valley, 522 Murphy, Nexen USA, Noble, Petrobras, Petronas, PGS, Repsol, Rockfield, Shell, 523 Spectrum, Equinor, Stone Energy, TGS, Total, WesternGeco, and Woodside 524 (http://www.beg.utexas.edu/agl/sponsors). The authors received additional support from the Jackson School of Geosciences, The University of Texas at Austin.

Brun, J.P. and Fort, X., 2004. Compressional Salt Tectonics (Angolan Margin). Tectonophysics, 382, pp.129-150.

Brun, J.P. and Fort, X., 2011. Salt tectonics at passive margins: Geology versus models. Marine and Petroleum Geology, 28(6), pp.1123-1145.

Cobbold, P.R. and Szatmari, P., 1991. Radial gravitational gliding on passive margins. Tectonophysics, 188(3-4), pp.249-289.

Curry, M. A. E., Peel, F. J., Hudec, M. R., and Norton, I. O., 2018, Extensional models for the development of passive-margin salt basins, with application to the Gulf of Mexico: Basin Research, v. 30, no. 6, p. 1180-1199.

Diegel, F. A., Karlo, J. F., Schuster, D. C., Shoup, R. C., and Tauvers, P. R., 1995, Cenozoic Structural Evolution and Tectono-Stratigraphic Framework of the Northern Gulf Coast Continental Margin, in Salt Tectonics: A Global Perspective, in Jackson, M. P. A., Roberts, D. G., and Snelson, S., eds., Volume 65, American Association of Petroleum Geologists.

Dooley, T. P., and Schreurs, G., 2012, Analogue modelling of intraplate strike-slip tectonics: A review and new experimental results: Tectonophysics, v. 574-575, p. 1-71.

Dooley, T. P., Hudec, M. R., Carruthers, D., Jackson, M. P. A., and Luo, G., 2017a, The effects of basesalt relief on salt flow and suprasalt deformation patterns - Part 1: Flow across simple steps in the base of salt: Interpretation, v. 5, no. 1, p. SD1-SD23.

Dooley, T. P., Hudec, M. R., 2017b, The effects of base-salt relief on salt flow and suprasalt deformation patterns - Part 2: Application to the eastern Gulf of Mexico, Interpretation, Volume 5, Issue 1

Dooley, T. P., Hudec, M. R., Pichel, L. M., and Jackson, M. P. A., 2018, The impact of base-salt relief on salt flow and suprasalt deformation patterns at the autochthonous, paraautochthonous and allochthonous level: insights from physical models, in McClay, K. R. and Hammerstein, J. A., Passive 

Margins: Tectonics, Sedimentation and Magmatism: Geological Society, London, Special Publications, no. $476,29 \mathrm{p}$.

Duffy, O. B., Fernandez, N., Peel, F. J., Hudec, M. R., Dooley, T. P., and Jackson, C. A.-L., Obstructed minibasins on a salt-detached slope: An example from above the Sigsbee canopy, northern Gulf of Mexico: Basin Research, v. 0, no. 0.

Fiduk, J. C., Clippard, M., Power, S., Robertson, V., Rodriguez, L., Ajose, O., Fernandez, D., and Smith, D., 2014, Origin, Transportation, and Deformation of Mesozoic Carbonate Rafts in the Northern Gulf of Mexico, Gulf Coast Association of Geological Societies Transactions, Volume 64.

Galloway, W.E., Bebout, D.G., Fisher, W.L., Dunlap, J.B., Jr, Cabrera-Castro, R., Lugo-Rivera, J.E., and Scott, T.M., 1991, Cenozoic. Salvador A. (ed), The Gulf of Mexico basin. The Geology of North America. Geological Society of America, Boulder, Colorado: vol J, pp 245-324

Galloway, W. E., 2008, Chapter 15: Depositional Evolution of the Gulf of Mexico Sedimentary Basin, in Miall, A. D., ed., Sedimentary Basins of the World, Volume 5, Elsevier, p. 505-549.

Gaullier, V., Brun, J.P., Gue, G. and Lecanu, H., 1993. Raft tectonics: the effects of residual topography below a salt decollement. Tectonophysics, 228(3-4), pp.363-381.

Hart, W., Jaminski, J., and Albertin, M., 2004, Recognition and Exploration Significance of Supra-Salt Stratal Carapaces in Salt Sediment Interactions and Hydrocarbon Prospectivity Concepts, Applications and Case Studies for the 21st Century, in Post, P. J., Olson, D. L., Lyons, K. T., Palmes, S. L., Harrison, P. F., and Rosen, N. C., eds., Volume 24, SEPM Society for Sedimentary Geology, p. 0.

Hudec, M. R., and Jackson, M. P. A., 2009, Interaction between spreading salt canopies and their peripheral thrust systems: Journal of Structural Geology, v. 31, no. 10, p. $1114-1129$.

Hudec, M. R., Norton, I. O., Jackson, M. P., and Peel, F. J., 2013, Jurassic evolution of the Gulf of Mexico salt basin: AAPG bulletin, v. 97, no. 10, p. 1683-1710.

Hudec, M. R., Jackson, M. P., and Peel, F. J., 2013, Influence of deep Louann structure on the evolution of the northern Gulf of MexicoGulf of Mexico Salt Influence: AAPG bulletin, v. 97, no. 10, p. 1711-1735.

Jackson, M.P., Vendeville, B.C. and Schultz-Ela, D.D., 1994. Structural dynamics of salt systems. Annual Review of Earth and Planetary Sciences, 22(1), pp.93-117.

Jackson, M. P. A., and Hudec, M. R., 2005, Stratigraphic record of translation down ramps in a passivemargin salt detachment: Journal of Structural Geology, v. 27, no. 5, p. 889-911.

Jackson, M. P. A., Hudec, M. R., \& Dooley, T. P., 2010, Some emerging concepts in salt tectonics in the deepwater Gulf of Mexico: intrusive plumes, canopy-margin thrusts, minibasin triggers and allochthonous fragments. In Geological Society, London, Petroleum Geology Conference series (Vol. 7, No. 1, pp. 899-912). Geological Society of London.

Jackson, M. P. A., and Hudec, M. R., 2017, Salt Tectonics: Principles and Practice, Cambridge, Cambridge University Press.

Krueger, S., Dynamics of tear faults in the salt-detached systems of the Gulf of Mexico [abs.], in Proceedings AAPG Annual Convention \& Exhibition Abstracts2010, Volume 19, p. 137-138.

Marton, G., Tari, G., \& Lehmann, C. (1998). Evolution of salt-related structures and their impact on the postsalt petroleum systems of the Lower Congo Basin, offshore Angola. In American Association of Petroleum Geologists International Conference and Exhibition, Rio de Janeiro. Extended Abstracts Volume (pp. 834-834).

Mount, V. S., Rodriguez, A., Chaouche, A., Crews, S. G., Gamwell, P., and Montoya, P., 2006, Petroleum system observations and interpretation in the vicinity of the K2/K2-North, Genghis Khan, and Marco Polo fields, Green Canyon, Gulf of Mexico.

Nettleton, L.L., 1955. History of concepts of Gulf Coast salt-dome formation. AAPG Bulletin, 39(12), pp.2373-2383.

Norton, I. O., Carruthers, D. T., and Hudec, M. R., 2016, Rift to drift transition in the South Atlantic salt basins: A new flavor of oceanic crust: Geology, v. 44, no. 1, p. 55-58.

Peel, F. J., Travis, C. J., and Hossack, J. R., 1995, Genetic Structural Provinces and Salt Tectonics of the Cenozoic Offshore U.S. Gulf of Mexico: A Preliminary Analysis, in Salt Tectonics: A Global Perspective, in Jackson, M. P. A., Roberts, D. G., and Snelson, S., eds., Volume 65, American Association of Petroleum Geologists.

Peel, F., Jackson, M., \& Ormerod, D.,1998,. Influence of major steps in the base of salt on the structural style of overlying thin-skinned structures in deep water Angola. In American Association of Petroleum Geologists International Conference and Exhibition, Rio de Janeiro, Brazil, November, Extended Abstracts Volume (pp. 366-367). 
Peel, F.J., 2014. The engines of gravity-driven movement on passive margins: Quantifying the relative contribution of spreading vs. gravity sliding mechanisms. Tectonophysics, 633, pp.126- 142.

Pindell, J., and Dewey, J. F., 1982, Permo-Triassic reconstruction of western Pangea and the evolution of the Gulf of Mexico/Caribbean region: Tectonics, v. 1, no. 2, p. 179-211.

Pichel, L. M., Peel, F. J., Jackson, C. A. L., and Huuse, M., 2018, Geometry and kinematics of salt-detached ramp syncline basins: Journal of Structural Geology, v. 115, p. 208 - 230.

Pichel, LM, A.-L. Jackson, C, Peel, F, Dooley, TP., 2019a, Base-salt relief controls salt-tectonic structural style, São Paulo Plateau, Santos Basin, Brazil. Basin Res.; 00: 1- 32

Pichel, L.M., Huuse, M., Redfern, J. and Finch, E., 2019b. The influence of base-salt relief, rift topography and regional events on salt tectonics offshore Morocco. Marine and Petroleum Geology, 103, pp.87113.

Pilcher, R. S., Kilsdonk, B., and Trude, J., 2011, Primary basins and their boundaries in the deep-water northern Gulf of Mexico: Origin, trap types, and petroleum system implications: AAPG Bulletin, v. 95, no. 2, p. 219-240.

Pilcher, R. S., Murphy, R. T., and McDonough Ciosek, J., 2014, Jurassic raft tectonics in the northeastern Gulf of Mexico: Interpretation, v. 2, no. 4, p. SM39-SM55.

Pindell, J., Graham, R., and Horn, B., 2014, Rapid outer marginal collapse at the rift to drift transition of passivemargin evolution, with a Gulf of Mexico case study: Basin Research, v. 26, no. 6, p. 701-725.

Pindell, J., Graham, R., and Horn, B. W., 2018, Role of outer marginal collapse on salt deposition in the eastern Gulf of Mexico, Campos and Santos basins: Geological Society, London, Special Publications, v. 476 , p. SP476.474.

Rowan, 1995, Structural Styles and Evolution of Allochthonous Salt, Central Louisiana Outer Shelf and Upper Slope, in Jackson MPA, Roberts DG, Snelson S. Salt Tectonics: A Global Perspective, AAPG Memoir 65, pp.199-228

Rowan, M. G., and Inman, K. F., 2011, Salt-related deformation recorded by allochthonous salt rather than growth strata: Gulf Coast Association of Geological Societies Transactions, v. 61, p. 379-390.

Rowan, M. G., Jackson, M. P., and Trudgill, B. D., 1999, Salt-related fault families and fault welds in the northern Gulf of Mexico: AAPG bulletin, v. 83, no. 9, p. 1454-1484.

Rowan, M. G., Peel, F. J. and Vendeville, B. C., 2004, Gravity-Driven Fold Belts on Passive Margins. in McClay K.R. ed., Thrust tectonics and hydrocarbon systems: AAPG Memoir 82, 157-182.

Rowan, M. G., 2014, Passive-margin salt basins: hyperextension, evaporite deposition, and salt tectonics: Basin Research, v. 26, no. 1, p. 154-182.

Rowan, M. G., 2018, The South Atlantic and Gulf of Mexico salt basins: crustal thinning, subsidence and accommodation for salt and presalt strata: Geological Society, London, Special Publications, v. 476, p. SP476.476.

Sawyer, D.S., Buffler, R.T. and Pilger Jr, R.H., 1991. The crust under the Gulf of Mexico Basin. Salvador A. (ed), The Gulf of Mexico basin. The Geology of North America. Geological Society of America, Boulder, Colorado: vol J, pp.53-72.

Salvador, A., 1987, Late Triassic-Jurassic paleogeography and origin of Gulf of Mexico basin: AAPG Bulletin, v. 71, no. 4, p. 419-451.

Schultz-Ela, D.D., 2001. Excursus on gravity gliding and gravity spreading. Journal of Structural Geology, 23(5), pp.725-731.

Steffens, G. S., Biegert, E. K., Summer, H. S., and Bird, D., 2003, Quantitative bathymetric analyses of selected deepwater siliciclastic margins: receiving basin configurations for deepwater fan systems: Marine and Petroleum Geology, v. 20, no. 6, p. 547 - 561.

Worrall, D.M. and Snelson, S., 1989. Evolution of the northern Gulf of Mexico. The geology of North America; an overview: Geological Society of America, v. A, pp.97-138.

Wu, S., Vail, P.R. and Cramez, C., 1990a. Allochthonous salt, structure and stratigraphy of the northeastern Gulf of Mexico. Part I: Stratigraphy. Marine and Petroleum Geology, 7(4), pp.318-333.

Wu, S., Bally, A.W. and Cramez, C., 1990b. Allochthonous salt, structure and stratigraphy of the northeastern Gulf of Mexico. Part II: Structure. Marine and Petroleum Geology, 7(4), pp.334-370 


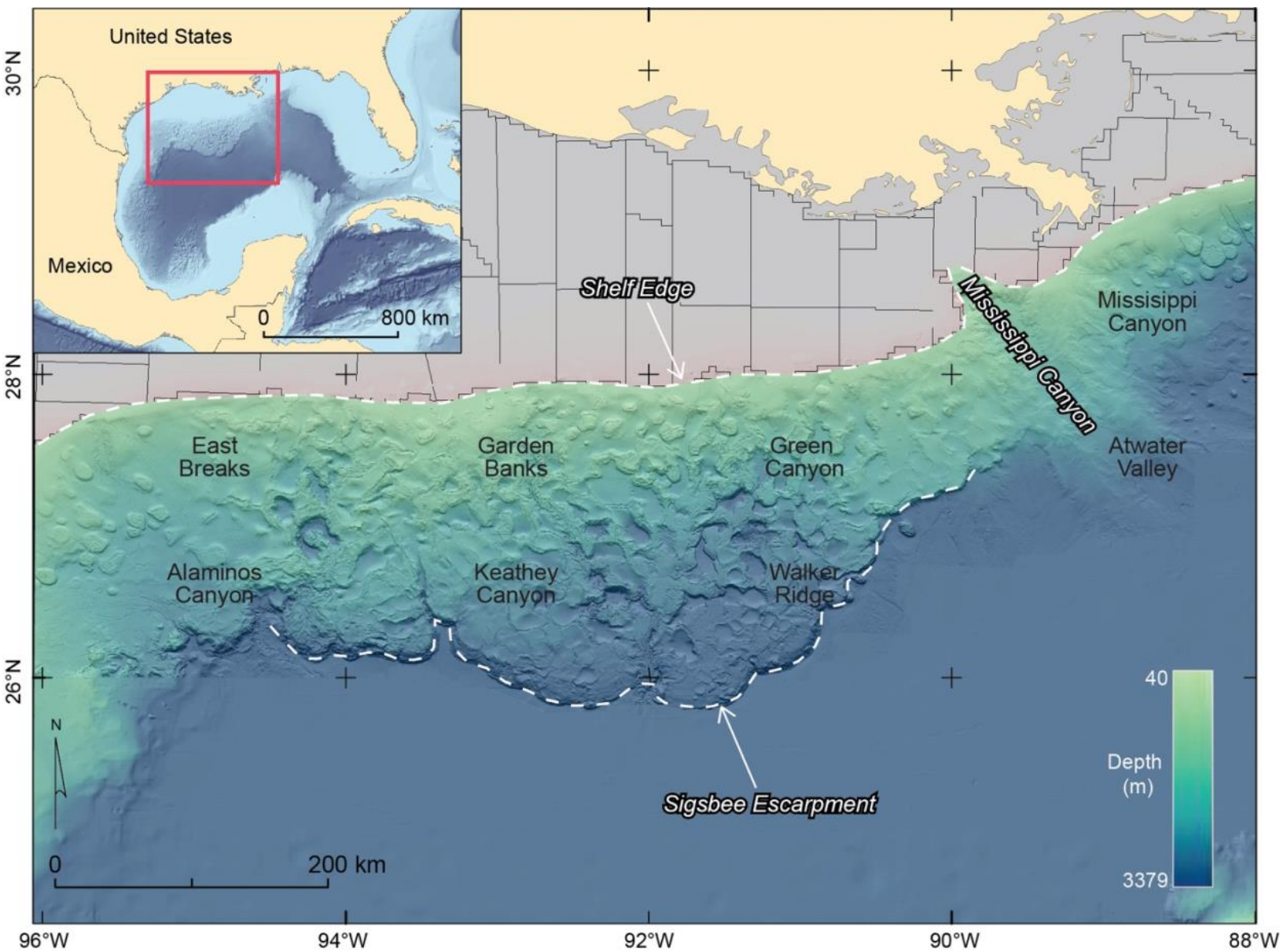

released due to confidentiality. The Sigsbee Escarpment and the Shelf Edge delimit the approximate extend of the Sigsbee salt

661 canopy. Labelled polygons represent the main protraction areas of the northern Gulf of Mexico slope. Bathymetry map is a 662 combination of data from the BOEM and NOAA. 

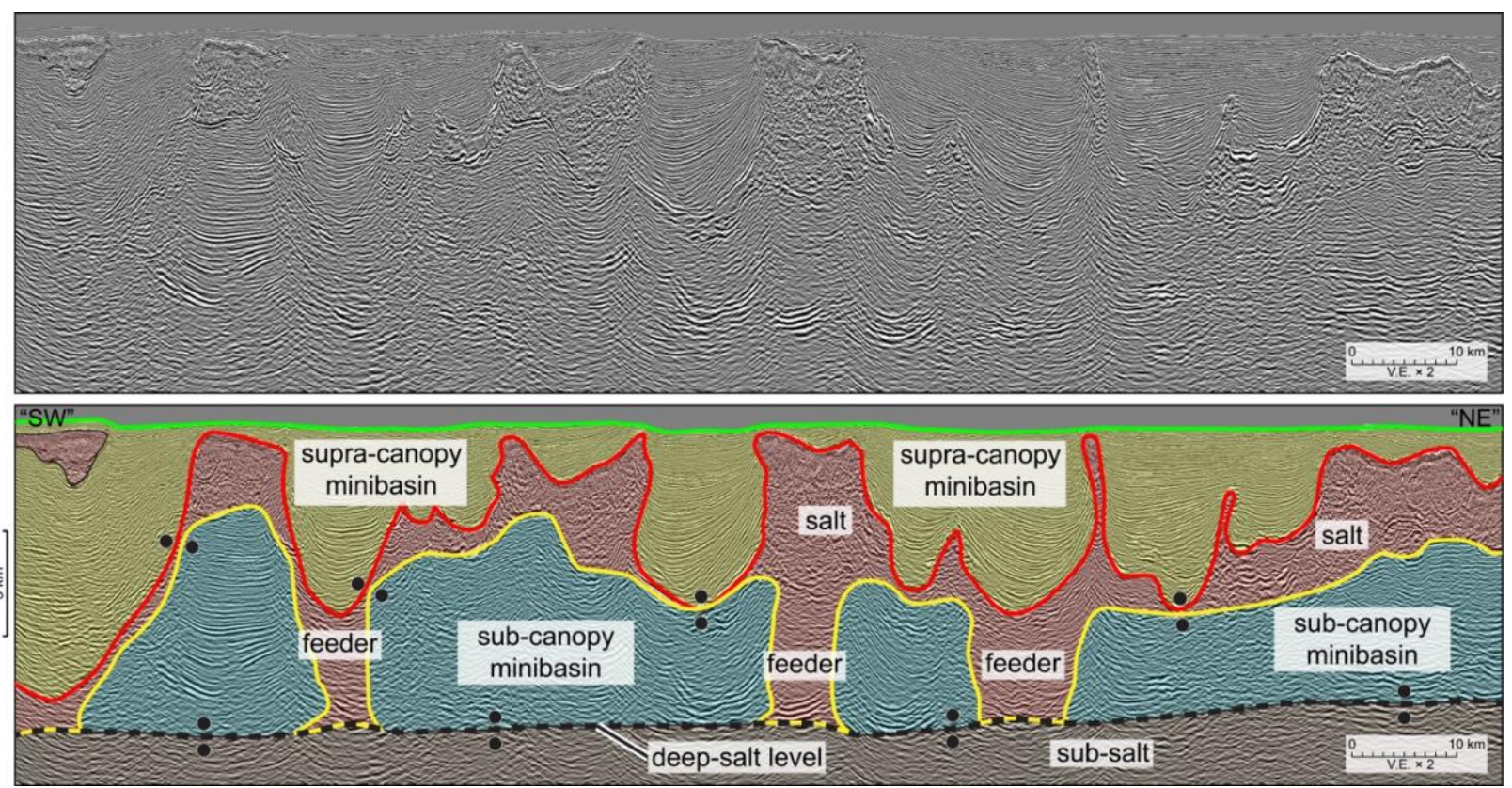

Figure 2. Uninterpreted (a) and interpreted (b) seismic section across the study area to illustrate the different structural elements 666 discussed throughout the text. The four mapped horizons are highlighted: seafloor (green), top Sigsbee Canopy surface 667 (corresponding to the base of supra-canopy minibasins) (red), base Sigsbee Canopy surface (also referred to as base-of-salt in the 668 text) (yellow) and deep salt level with undifferentiated autochthonous and allochthonous salt (dashed black line). The feeders are 669 the vertical conduits that connect the two salt levels. 


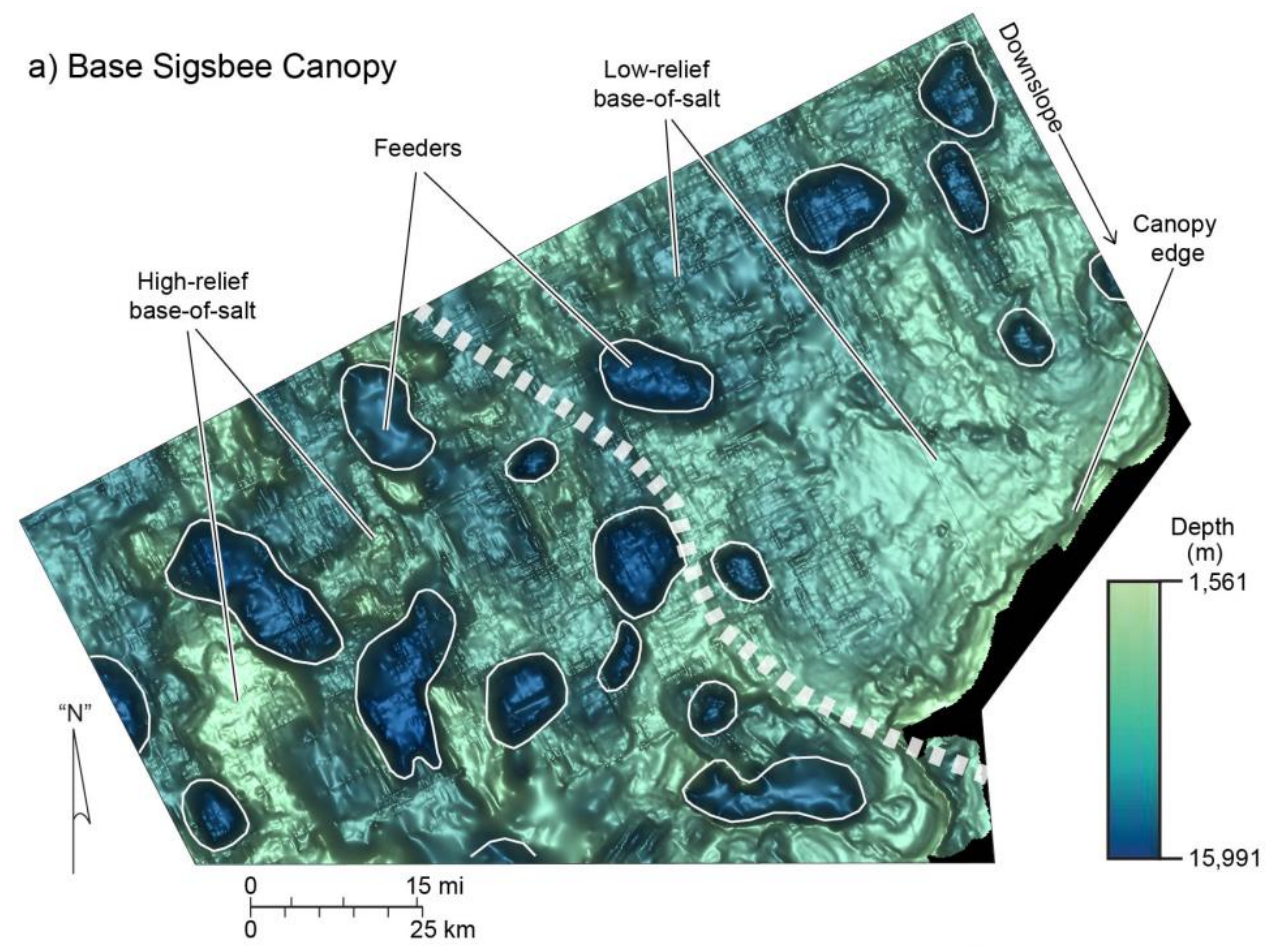

b) Top Sigsbee Canopy

671

673

674

675

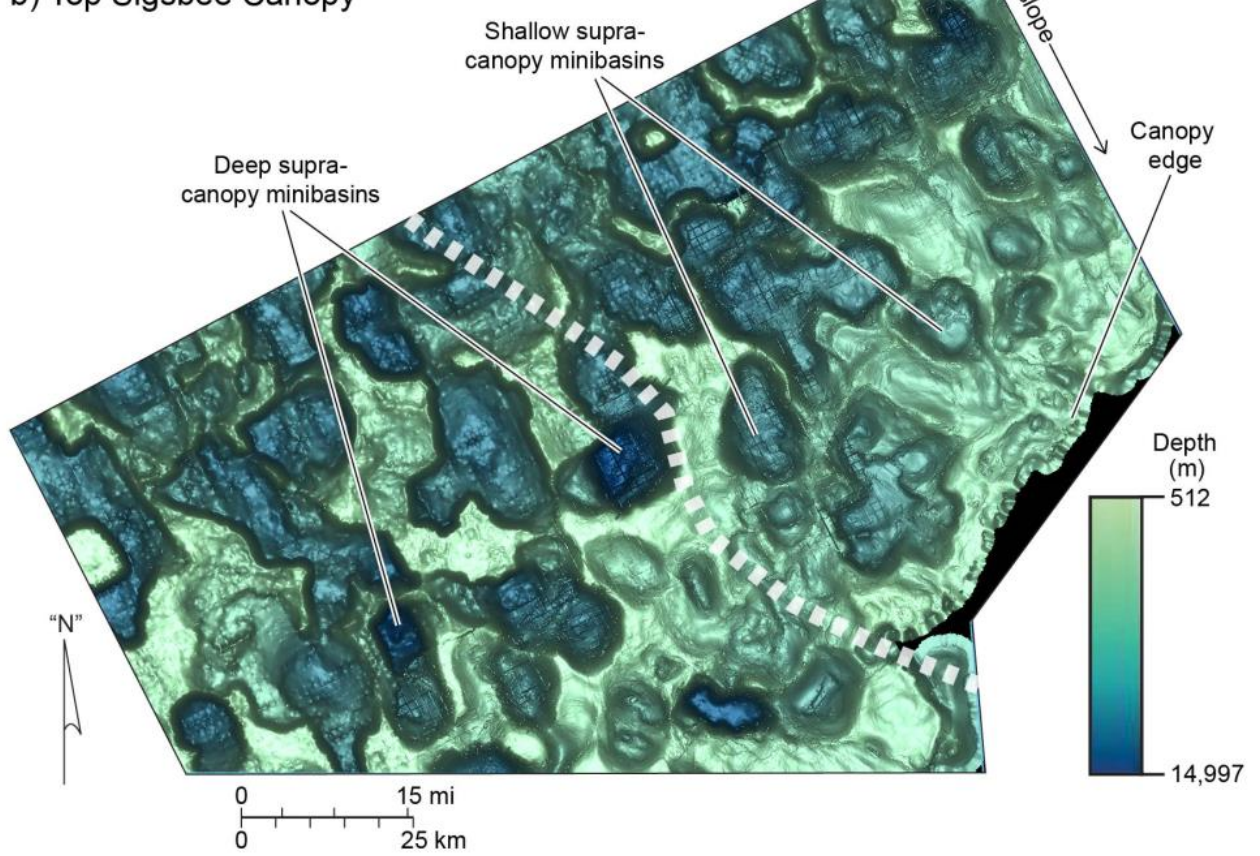

Figure 3. a) Map view of base Sigsbee Canopy surface, where the marked structural lows represent feeders that connect the deep and shallow salt levels. b) Map view of top Sigsbee Canopy, where each structural low represents a minibasin hat has subsided into the salt canopy. Maps have been rotated and are oriented according to a false North due to confidentiality. The dashed line 
a)
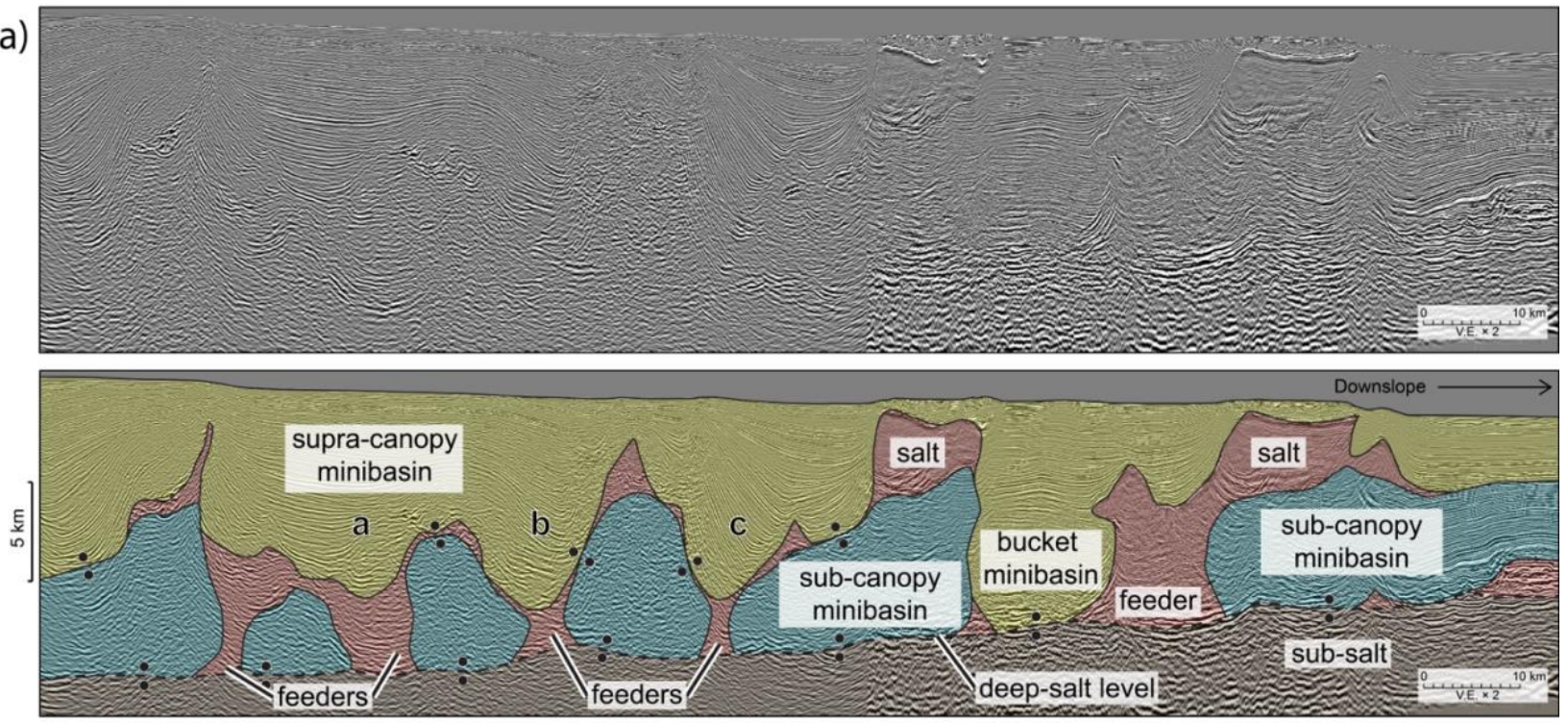

b)
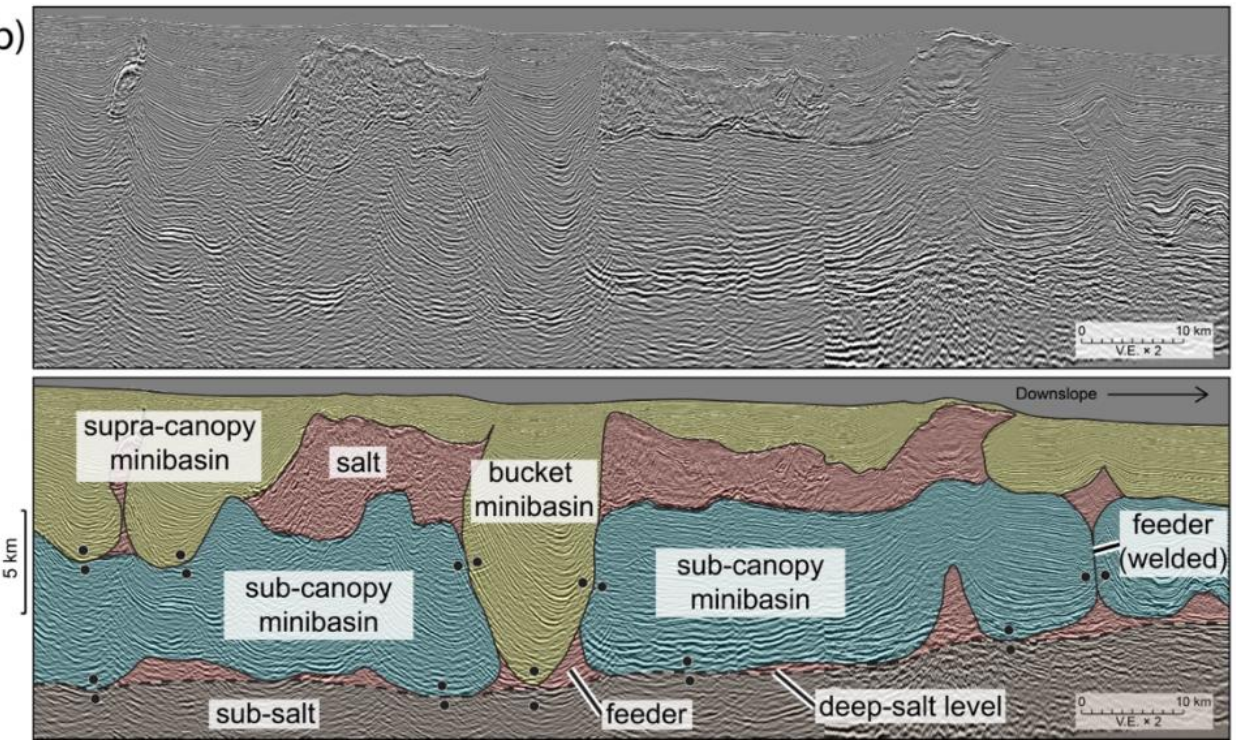

677

Figure 4. Uninterpreted and interpreted seismic sections across the "Southwest" domain. Both sections show a landward dipping

679 deep salt level. Sub-canopy primary sequence is very rugose and discontinuous with many feeders connecting the deep salt and

680 canopy salt levels. Feeders are abundant, especially in a). Feeders range in height and wide but most of them, contain a bucket

681 minibasin inside. Bucket minibasins can be partially filling the feeder, or completely filling the feeder and welded to the deep salt

682 level inside the feeder. Overall, the contact area between the sub-canopy and supra-canopy sequences is very rugose and sinuous. 
a)
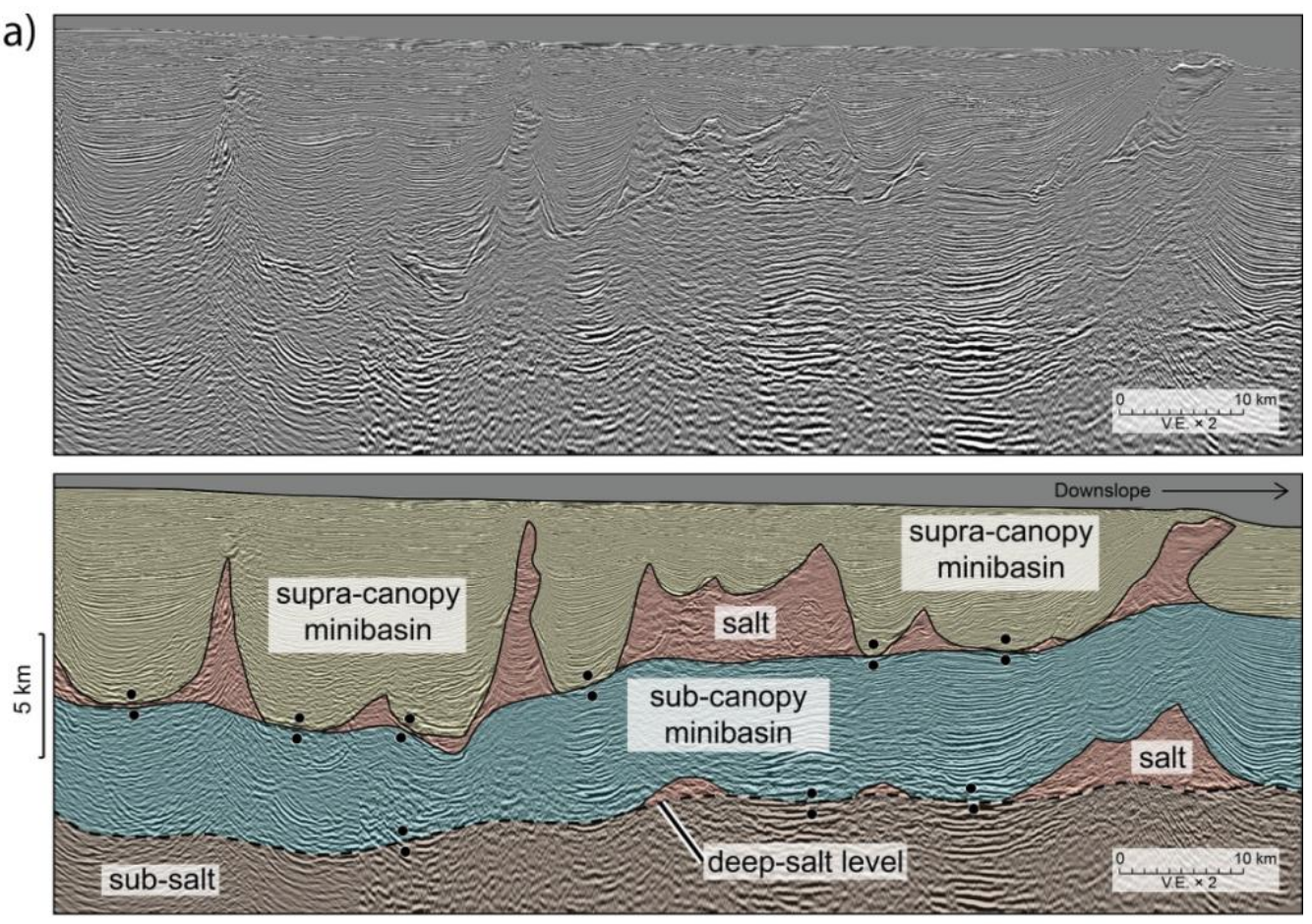

b)
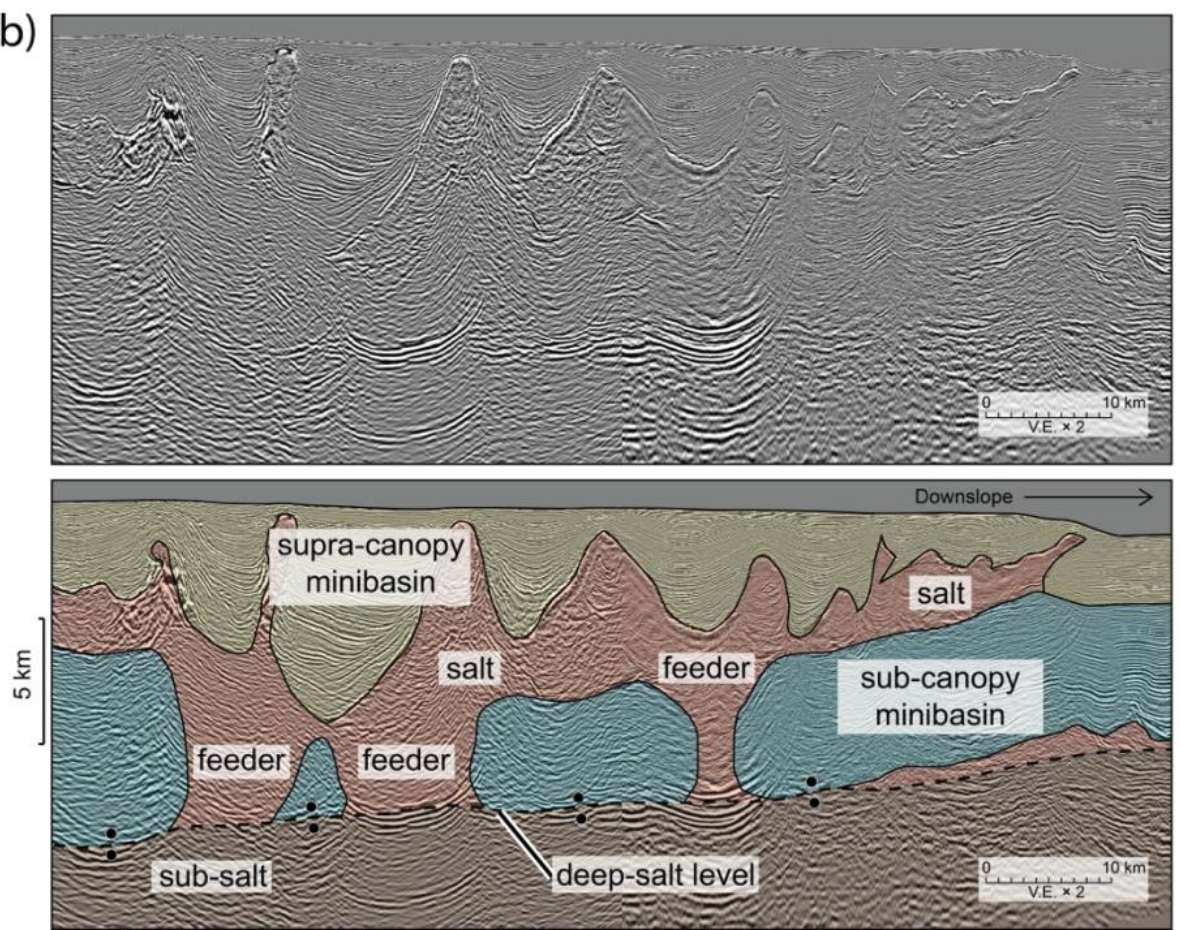

Figure 5. Uninterpreted and interpreted seismic sections across the "Northeast" domain. Both sections show a landward dipping deep salt level. In section a), the sub-canopy sequence is very continuous and relatively smooth flat portions, except for areas where the slope of the surface changes. The supra-canopy minibasins on top are welded to the smooth sub-canopy sequence. In section b) the sub-canopy is discontinuous with various feeders connecting the shallow and deep salt levels. Supra-canopy minibasins on top are relatively thin and do not weld to the sub-canopy sequence. Overall, section a) illustrates a relatively smooth

690 contact surface between supra-and sub-canopy sequence, while section b) illustrates and area where there is no contact surface 691 between sub-and supra-canopy sequences. 


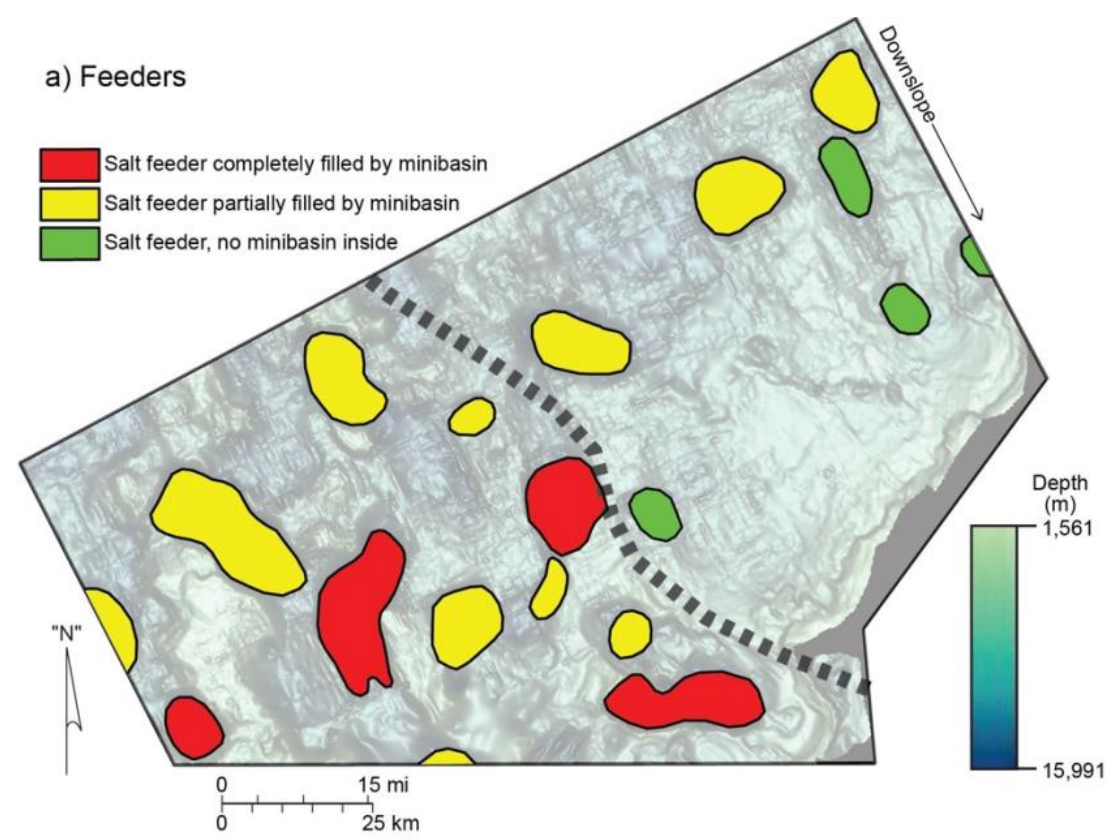

b) Obstructed minibasins

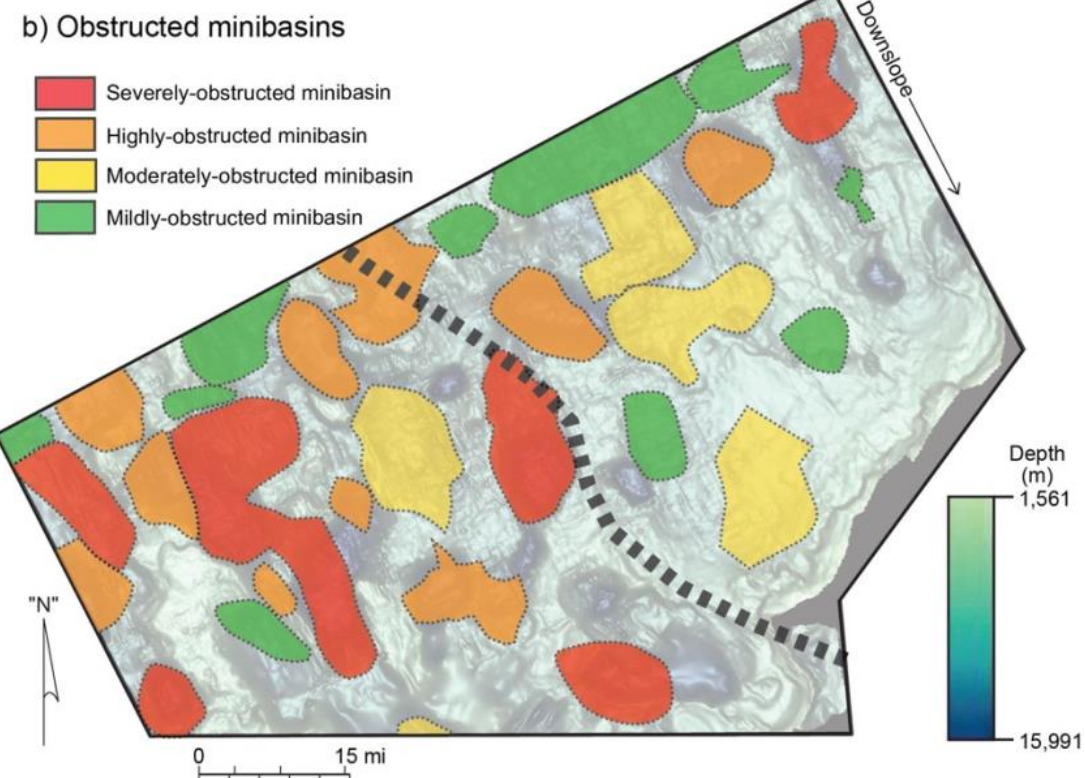

Figure 6. a) Map view showing the outlines of feeders interpreted in the study area. Feeders are colored depending on whether they are completely or partially filled with a supra-canopy minibasin inside, or whether they do not have a supra-canopy minibasin inside. Notice the absence of feeders completely filled with minibasins inside in the "Northeast" domain, as well as the absence of empty feeders in the "Southwest" domain. Dashed black line represents hypothetical boundary between "Northeast" and "Southwest" domains. Background map corresponds to the Base of Sigsbee Canopy horizon (Fig. 3a). b) Map view showing the outlines of obstructed minibasins colored according to severity of obstruction (from Duffy et al., 2019). Notice the abundance of obstructions classified as severe or highly obstructed in the "Southwest" domain, as compared to the "Northeast" domain. Background map corresponds to the Base of Sigsbee Canopy horizon (Fig. 3a). The dashed line indicates the approximate boundary between the two structural domains that are described in the text. 
a)

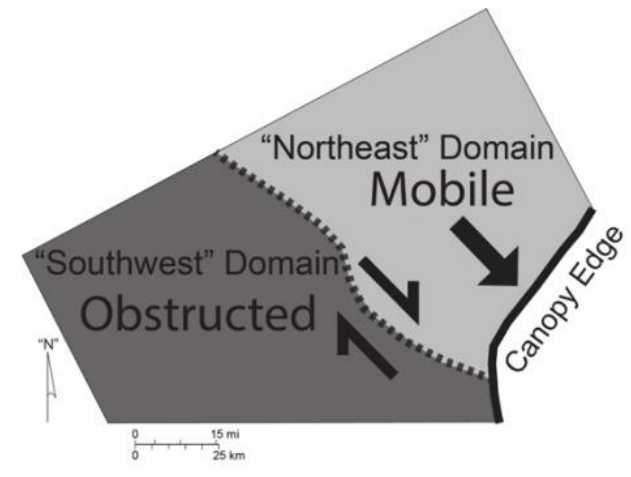

b)

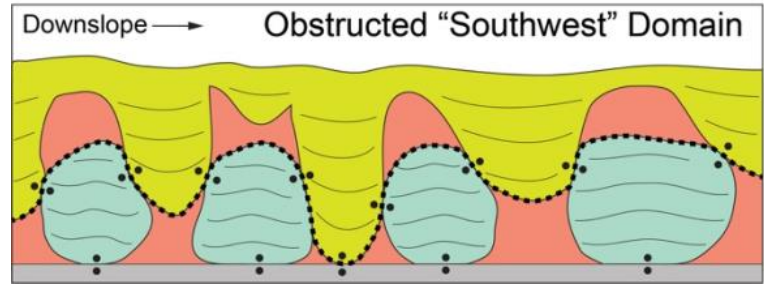

c)

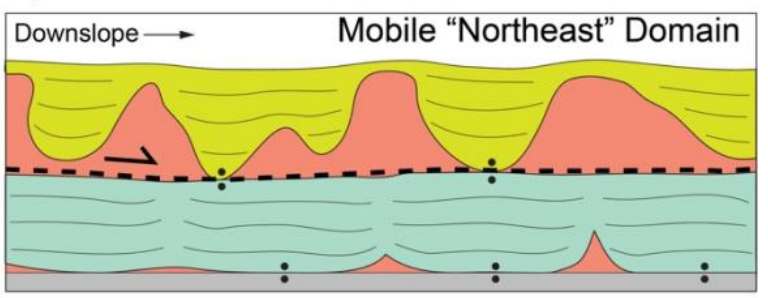

d)

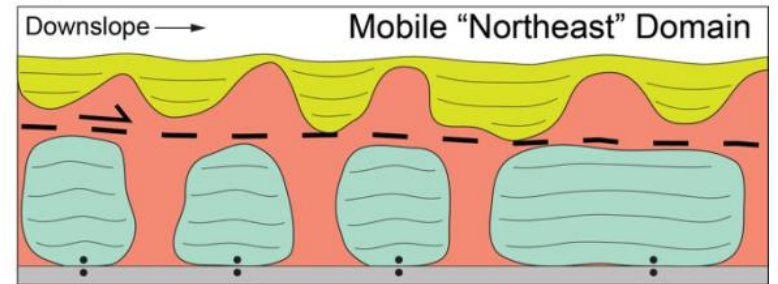

Figure 7. a) Map view of the outline of the study area and the approximate boundary between the two differentiated domains: the "Northeast" mobile domain, and the "Southwest" obstructed domain. The differential potential for mobility would result in a dextral strike-slip boundary. b), c) and d) Synoptic sections of the different structural styles observed in the study area. b) Synoptic section synthesizing the elements observed in the seismic sections of the Western domain area: abundant and prominent feeders that are completely or partially infilled with supra-canopy minibasins. There is not a clear detachment surface between the supracanopy cover and the sub-canopy sequence, but rather a sinuous and irregular contact surface defined by the abundant welds. c) Synoptic section of the "Northeast" domain where the base of shallow salt has very low relief, with supra-canopy minibasins above welded or not welded on top of the sub-canopy sequence. d) Synoptic section of the "Northeast" domain where base of shallow salt has very high relief, with abundant feeder (smaller than in the West), but supra-canopy minibasins might not always be welded or sunk into the feeders. In c) and d) examples, there is a potential detachment surface between the supra-canopy cover and the

715 underlying sub-canopy sequence. 
a) Carapace-block transport Intact, untransported carapace

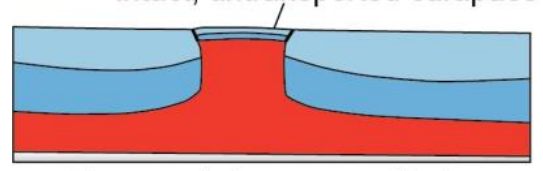

Transported carapace blocks

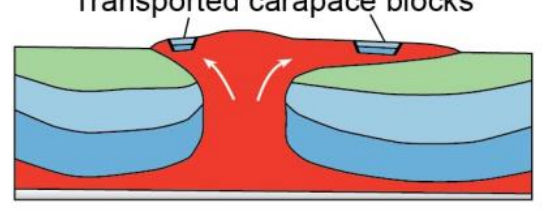

b) Minibasin transport Untransported minibasin

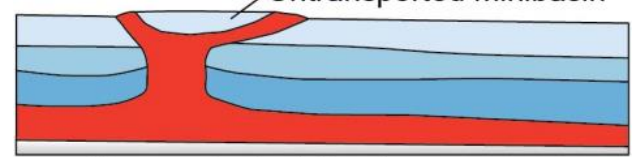

Transported minibasin

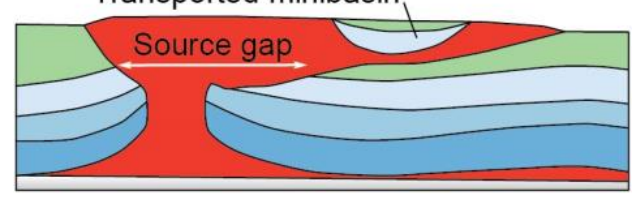

\section{C) Ramp Syncline Basin}
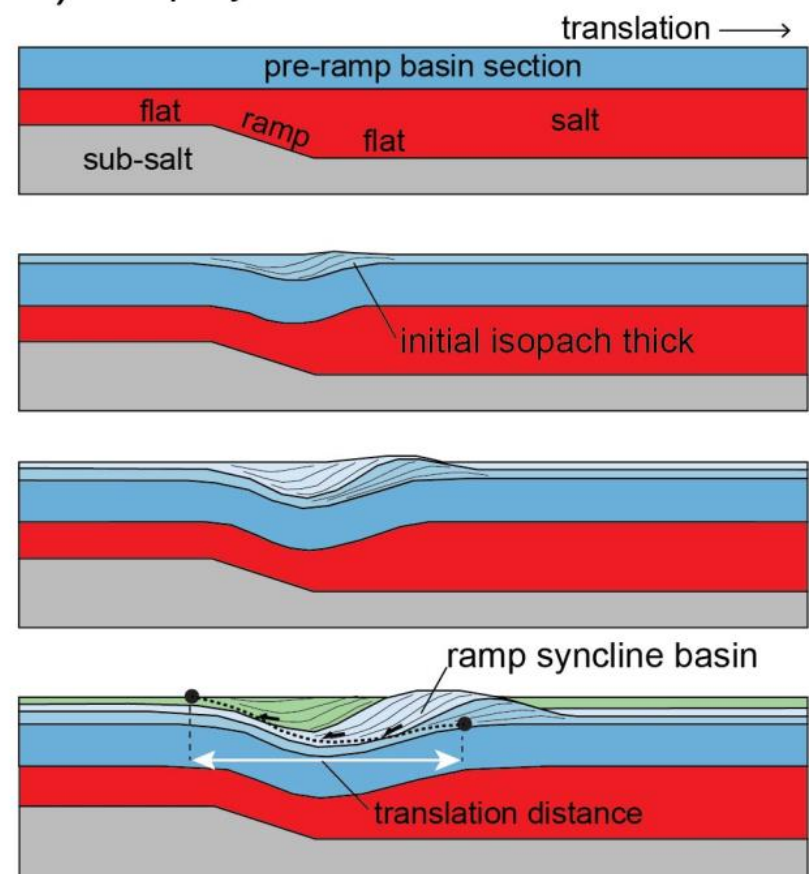

Figure 8. Schematic cartoons of lines of evidence for identifying large-magnitude transport of advancing salt canopies. (a) and (b). Schematic restorations of transport and emplacement of a carapace of two types of roof material: (a) carapace-blocks and (b) entire minibasins (modified from Jackson and Hudec, 2018). Note that in both cases, the transport of roof material with the advancing sheet has placed the older sediments contained in the carapace or in the minibasin directly above the younger sediments in the sub-canopy section. Identifying the source gap from where the roof material was originated can provide estimates of the transport distance. (c) Evolutionary model of a salt-detached ramp syncline formation (from Pichel et al., 2018). The ramp syncline basin forms by translation of the sedimentary cover over a salt layer. As the cover is translated over the base salt ramp, new accommodation space is created on top. Translation movement is recorded by the onlap offset. Distance between oldest and youngest ramp-related onlaps provide estimates for the transport distance. 

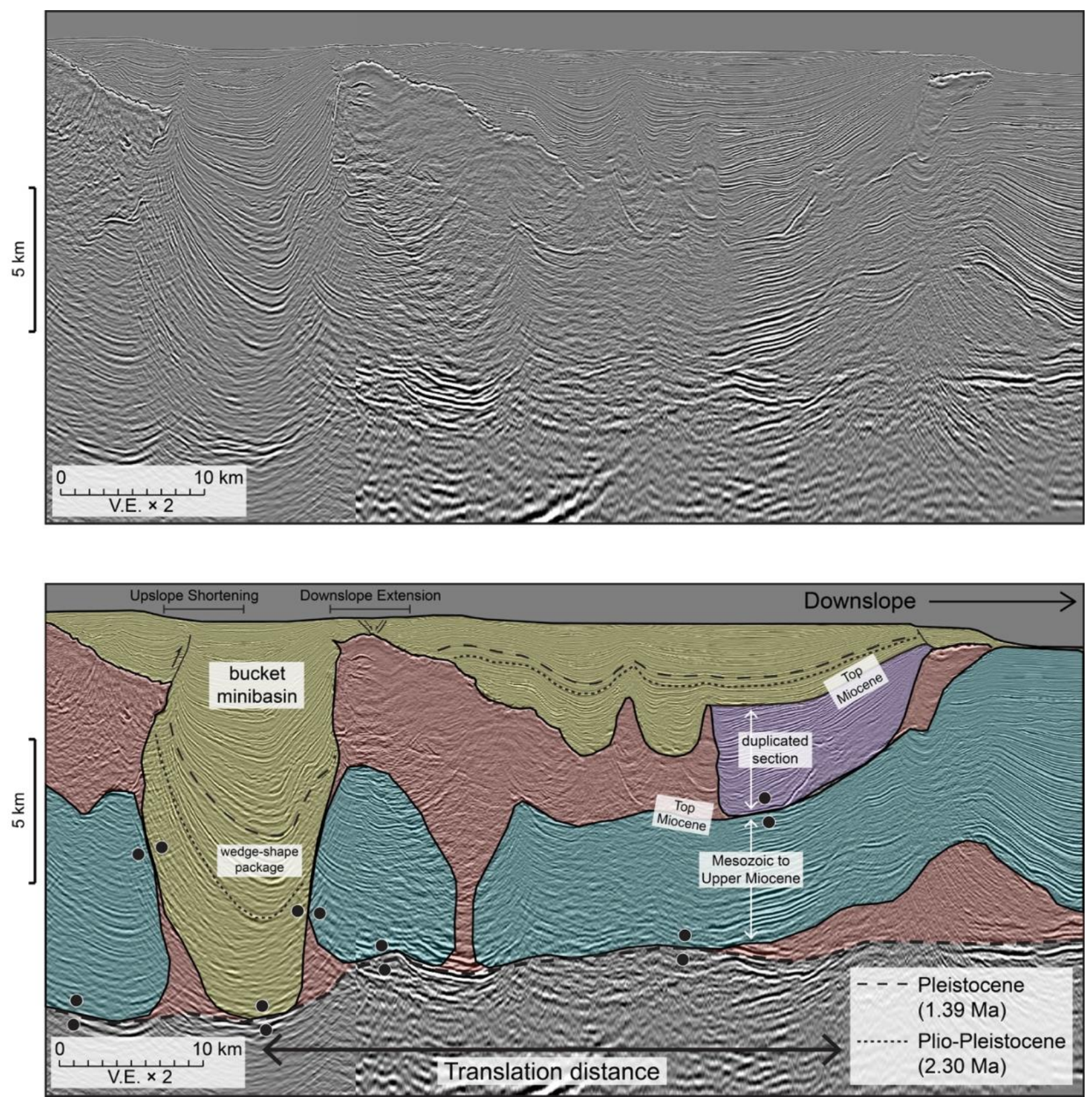

Figure 9. Uninterpreted and interpreted seismic section across a far-travelled minibasin and its probable source area (feeder)

sequence sediments of younger age, thus the minibasin contains a duplicated section. The minibasin is interpreted as a rafted or

732 far-travelled minibasin source from a feeder located several tens of kilometers up-dip which at present-day is occupied by a

733 bucket minibasin. Ages are based on GBDS surface picks of biostratigraphy markers from wells in the study area. 

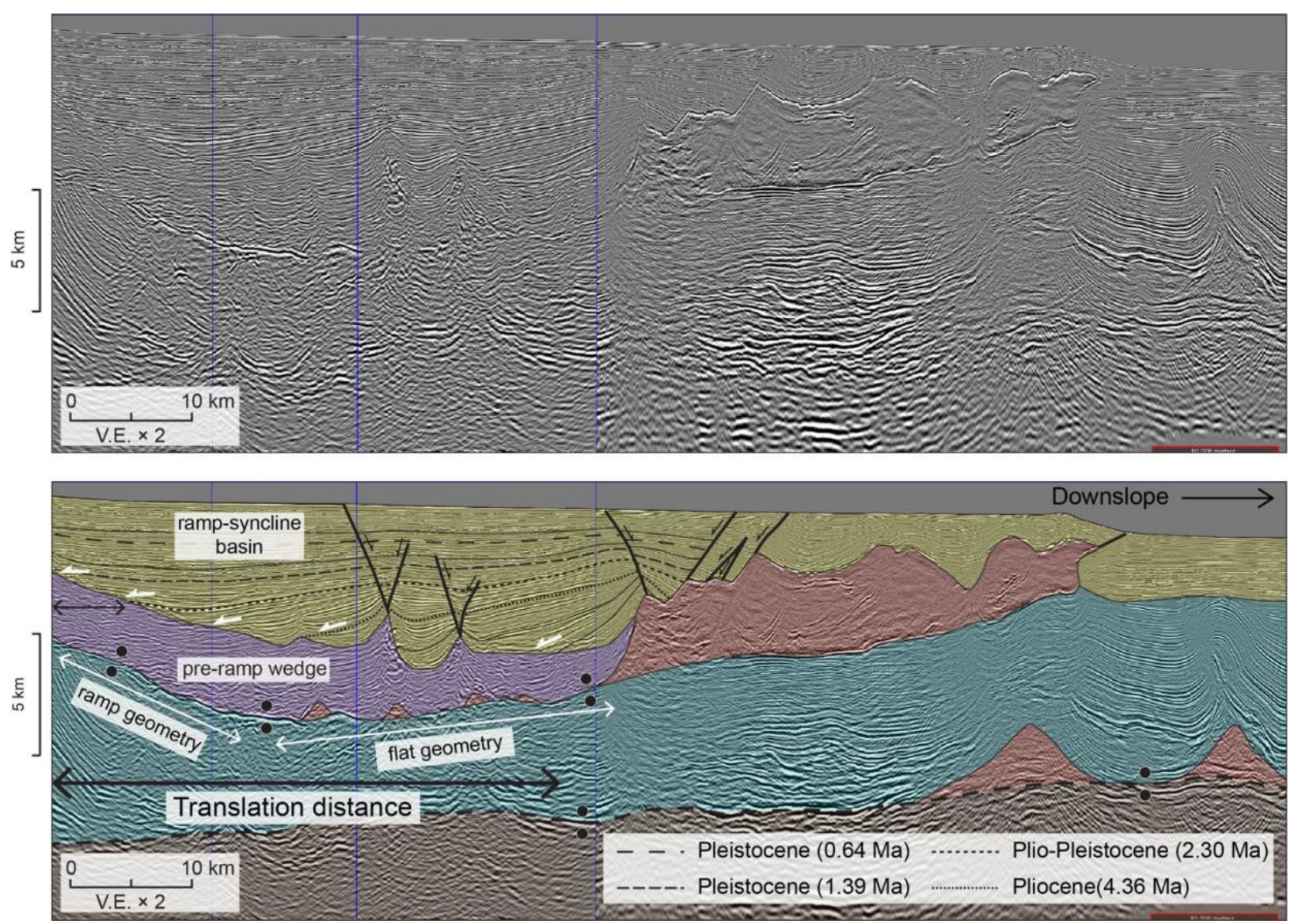

Figure 10. Uninterpreted and interpreted seismic section across a ramp syncline basin in the study area. The minibasin contains 739 prograding updip in the section. The basin is interpreted as a ramp-syncline basin formed in relation with the ramp-flat geometry of the sub-canopy (primary) topography. The present-day distance from the oldest onlap to the updip location of the flat-to-ramp transition (not seen in the section) gives an estimate of the transport distance of several tens of kilometers. Ages are based on GBDS surface picks of biostratigraphy markers from wells in the study area. 
a)

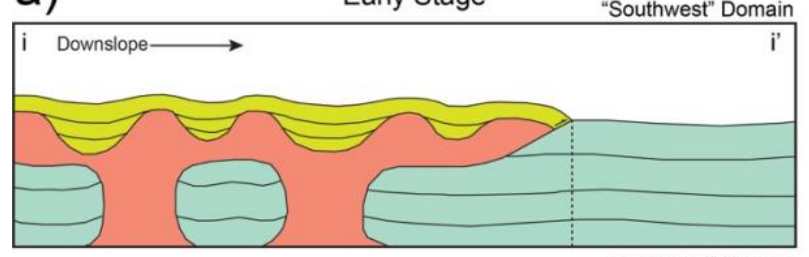

"Northeast" Domain

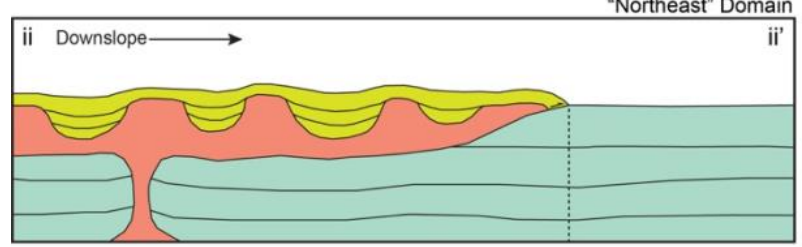

b)
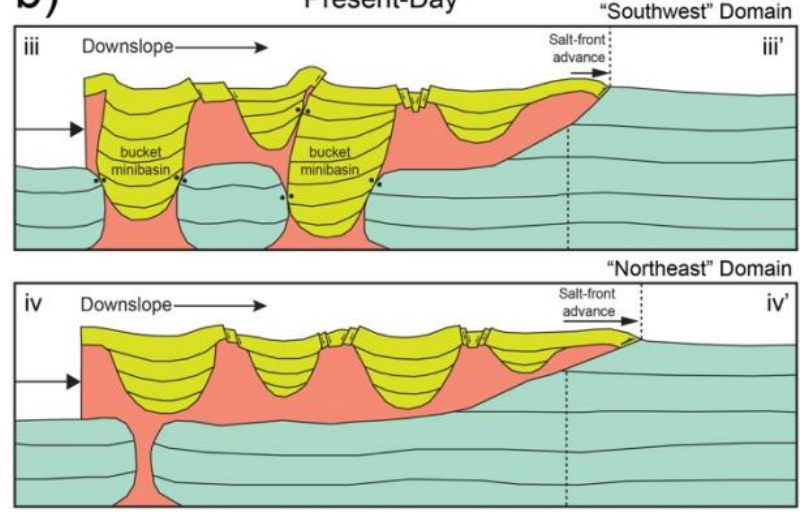

c)

i Early Stage
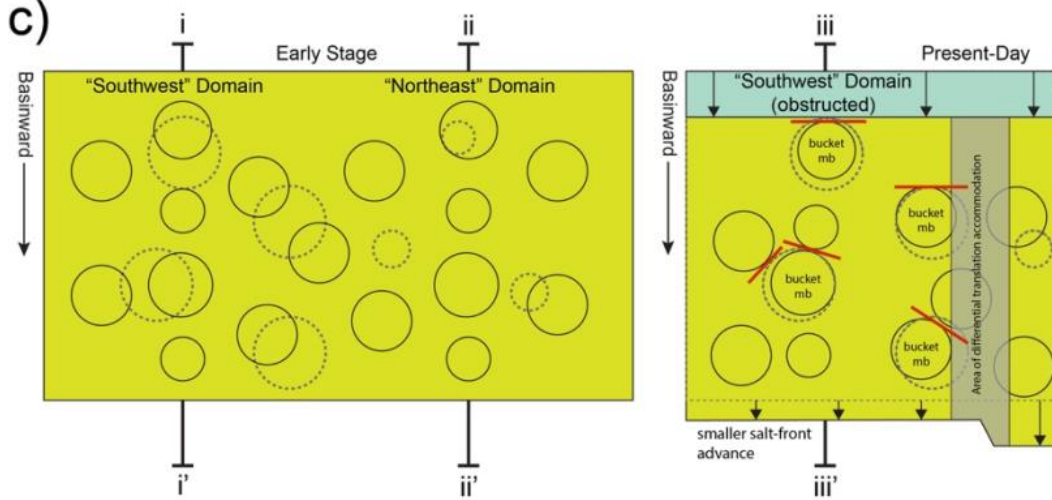

iv

"Northeast" Domain (mobile)

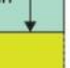

Feeder (base of salt)
Minibasin (supra-canopy
Translation and salt-front Translation

Shortening (updip of obstructed bucket minibasin)

iv Location of schematic

Figure 11. (a)- (b). Synoptic cross section sketches illustrating the evolution of the "Southwest" Domain and the "Northeast" Domain, from an early stage (both domains are mobile) to a late stage, where the "Southwest" Domain is obstructed and the "Northeast" Domain is still mobile. c) Synoptic plan-view sketch illustrating the differential evolution between the two domains. The obstruction of the "Southwest" Domain and subsequent continuous translation of the "Northeast" Domain results in differential salt advance in the front. A broad area is delimited in between the two domains, where the differential translation needs to be accommodated. Deformation can be accommodated in a diffuse way (e.g. short fault segments along minibasin boundaries as opposed to a large linear strike-slip fault). 
a)
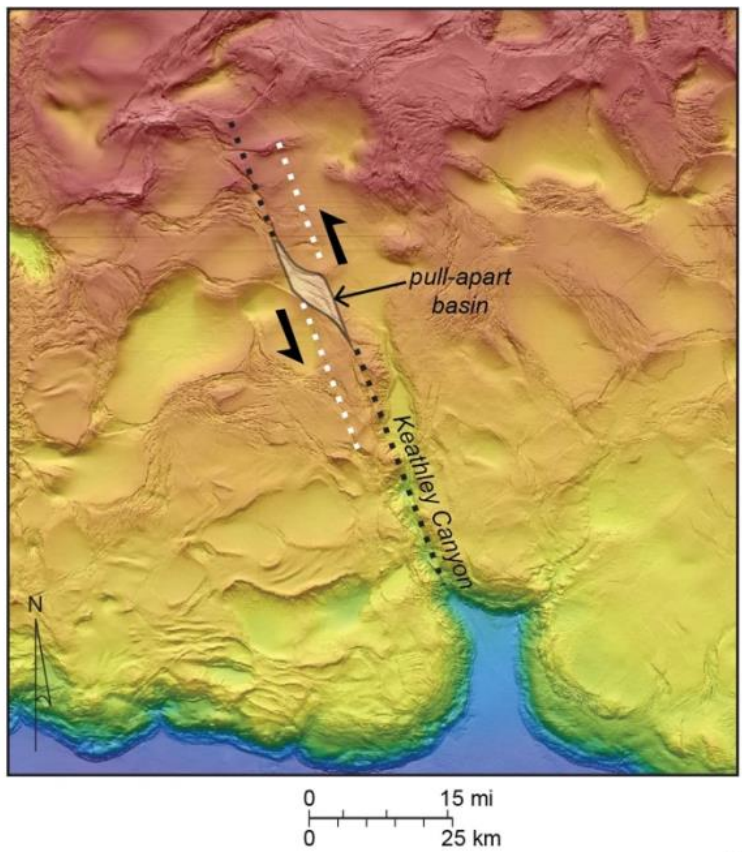

b)

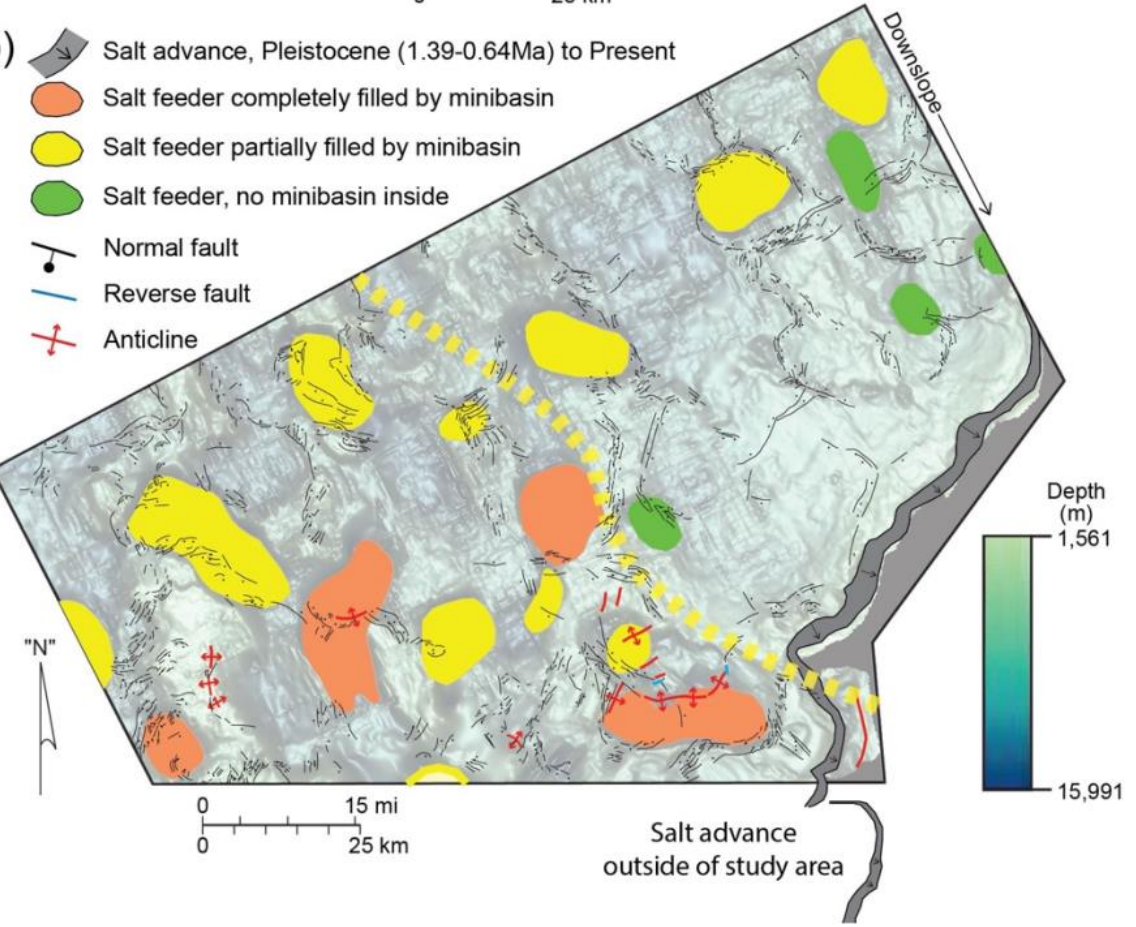

Figure 12. a) Seafloor map of the west of Sigsbee canopy showing a long and straight left-lateral strike slip zone in Keathley Canyon (after Dooley and Schreurs, 2012) associated to differential downslope translation of the Sigsbee canopy. b) Map of structures observed in the seafloor of the study area. Background map corresponds to the Base of Sigsbee Canopy horizon (Fig. 3a). Notice that most widespread structures correspond to faults grouped in deformation zones along minibasin boundaries (e.g. grabens) indicating a major component of stretching. Shortening structures (reverse faults and folds) are limited to the "Southwest" domain. No clear long and straight right-lateral strike slip deformation zone is observed in the seafloor along the boundary (yellow dashed line) between the two domains. However, Pleistocene to Present-Day differential salt advance is indicated by the interpretation of sub-canopy salt cutoffs, with higher advance occurring at the "Northeast" domain. 